\title{
The 2009 Recovery Act: Stimulus at the Extensive and Intensive Labor Margins
}

\author{
Bill Dupor \\ and \\ M. Saif Mehkari \\ Working Paper 2014-023B \\ https://doi.org/10.20955/wp.2014.023
}

January 2015

FEDERAL RESERVE BANK OF ST. LOUIS

Research Division

P.O. Box 442

St. Louis, MO 63166

The views expressed are those of the individual authors and do not necessarily reflect official positions of the Federal Reserve Bank of St. Louis, the Federal Reserve System, or the Board of Governors.

Federal Reserve Bank of St. Louis Working Papers are preliminary materials circulated to stimulate discussion and critical comment. References in publications to Federal Reserve Bank of St. Louis Working Papers (other than an acknowledgment that the writer has had access to unpublished material) should be cleared with the author or authors. 


\title{
The 2009 Recovery Act: Stimulus at the Extensive and Intensive Labor Margins*
}

\author{
Bill Dupor ${ }^{\dagger}$ and M. Saif Mehkari ${ }^{\ddagger}$
}

January 15, 2016

\begin{abstract}
This paper studies the effect of government stimulus spending on a novel aspect of the labor market: the differential impact of spending on the total wage bill versus employment. We analyze the 2009 Recovery Act via instrumental variables using a new instrument, the spending done by federal agencies that were not instructed to target funds towards harder hit regions. We find a moderate positive effect on jobs created/saved (i.e., the "extensive margin") and also a significant increase in wage payments to workers whose job status was safe without Recovery Act funds (i.e., the "intensive margin"). Our point estimates imply that roughly one-half of the wage payments resulting from the act were paid at the intensive margin. To provide a theoretical underpinning for the estimates, we build a micro-founded dynamic model in which a firm meets new government demand with a combination of new hiring and increasing existing workers' average hours. Faced with hiring costs and an overtime premium, the firm responds by increasing hours along both margins. Our model analysis also provides insight into how government spending policy should be structured to lower the cost of generating new jobs. Finally, we catalogue survey evidence from Recovery Act fund recipients that reinforces the importance of the intensive labor margin.
\end{abstract}

Keywords: fiscal policy, intensive and extensive labor margins, the 2009 Recovery Act.

JEL Codes: D21, D24, E62.

\footnotetext{
${ }^{*}$ The authors thank Emilee Dufford and Peter McCrory for helpful research assistance as well as helpful suggestions from the editor and referee. The authors also thank audience members at Cal State Fullerton, the Midwest Macro Conference, the University of Richmond, Vanderbilt University and especially Troy Davig and Peter McCrory for useful comments. A repository containing government documents, data sources, a bibliography and other relevant information pertaining to the Recovery Act is available at billdupor.weebly.com. The analysis set forth does not reflect the views of the Federal Reserve Bank of St. Louis or the Federal Reserve System.

${ }^{\dagger}$ Federal Reserve Bank of St. Louis, william.d.dupor@stls.frb.org, billdupor@gmail.com.

${ }^{\ddagger}$ University of Richmond, smehkari@richmond.edu.
} 


\section{Introduction}

The American Recovery and Reinvestment Act of 2009 (hereafter, the Recovery Act) was the largest countercyclical fiscal intervention in the U.S. over at least the past 75 years. The Recovery Act had three main goals: to save and create jobs, to invest in infrastructure, education, health and renewable energy, and to provide temporary relief to those most affected by the recession. The law's total budget impact was $\$ 840$ billion. This paper studies the act's government purchases component which constituted (depending on the precise definition of purchases) between $31 \%$ and $42 \%$ of the entire program. ${ }^{1}$

The Recovery Act had three main goals: to create and save jobs, to provide temporary relief for those most affected by the recession and to invest in infrastructure, education, health, and renewable energy. This paper focuses on the first goal. In assessing the law's impact in terms of this goal, a Council of Economic Advisers (2014) study, which includes a comprehensive survey of research on the act, concluded that "the Recovery Act, by itself, saved or created about 6 million job-years, where a job-year is defined as one full-time job for one year." This translates into a cost of $\$ 140,000$ per job, which is significantly higher than the typical compensation of $\$ 48,000$ to a full-time worker in the U.S. overall economy at the time of the act's passage.

We seek to better understand the cost of job creation by relating it to the act's effect on wage payments. First, we use cross-sectional instrumental variables to estimate the effect of the government purchases component of the act on both the number of jobs created/saved and changes in the total wage bill. The point estimates from our benchmark specification imply that government stimulus spending passes approximately one-for-one into higher wage payments; however, only onehalf of the wage payments went to savings/creating jobs. The remainder went to workers whose job status was not dependent on Recovery Act funds. Second, we construct and analyze a microfounded dynamic firm problem to show, consistent with our empirical results, that a significant portion of government stimulus can affect the labor market through higher wage payments to workers rather than saving and creating jobs.

Intuitively, in response to an increase in government demand, a firm might hire new workers or else keep existing workers that it was about to fire. Under this scenario, the government has effectively taken or kept people out of unemployment. We call this the extensive margin effect. Alternatively, a firm might simply meet the government demand for goods by increasing the hours of workers whose employment status did not depend upon stimulus funds. We call this the intensive margin effect. ${ }^{2}$ Unlike previous studies, in addition to the extensive margin, we also analyze the

\footnotetext{
${ }^{1}$ Drautzburg and Uhlig (2013) do an item-by-item categorization of the act into government purchases of goods and services, tax relief and entitlement payments to individuals. They report that $\$ 350$ billion of the act's dollars were government purchases. The Recovery Accountability and Transparency Board (RATB), the official agency charged with monitoring the act's implementation, does not separately parse the government purchases component. The closest analogue to government purchases used by the RATB is their category of "contracts, grants and loans" which totaled $\$ 261$ billion.

${ }^{2}$ The intensive margin effect will also include increases in the wage rate paid to these latter types of workers.
} 
intensive margin and relate it to the cost of job creation.

We view the distinction between the extensive and the intensive margin effects as important because with imperfect insurance of employment income, the brunt of the welfare costs of the 20072009 recession was likely felt by persons losing their jobs. ${ }^{3}$ Alleviating unemployment through stimulus job creation and savings acts as a crude form of social insurance. As such, increasing the number of bodies at work (i.e. changes along the extensive margin) may have been preferred to increasing the income of those already employed (i.e. changes along the intensive margin). ${ }^{4}$

Our empirical work uses quarterly reports filed by over 570,000 individual recipient organizations (businesses, non-federal government agencies and non profits) of Recovery Act funds. The reports give zip code level detail on spending. We aggregate this data to the level of local labor markets using U.S. Census Journey to Work commuting data. ${ }^{5}$ We have a total of 918 local markets, the majority of which each consist of 2 to 4 counties.

We measure the variation in employment and the total wage bill across labor markets following the act's passage and compare these to the markets' Recovery Act spending. Following standard techniques, these differences will deliver an estimate of the causal impact of the spending on each outcome variable. A significant intensive margin effect would be indicated by a large wage bill effect combined with a relatively small employment effect.

In estimating the effects of the act, we have concerns about potential endogeneity in the allocation of government spending across local markets: Some components of the Recovery Act were targeted differently across geographic areas depending on the local severity of the recession. Many of the spending components, however, were not allocated to more economically distressed, or alternatively stronger, areas. ${ }^{6}$ We add these components together to develop a new instrument for total Recovery Act spending. This instrument is highly correlated with our treatment variable: total Recovery Act spending.

To determine which components of the act were exogenous we analyze the act, the federal codes and regulations cited by the act, and implementation guidances written by the agencies tasked with allocating the funds. Examples of the exogenous components include the Energy Efficiency and Renewable Energy program (Department of Energy), Public Building Fund (General Services Administration), the Capital Transit Assistance program (Federal Transit Administration) and the Special Education Fund (Department of Education). A full discussion of each program's

While distinguishing between increased hours per worker versus an increased wage rate is interesting, teasing out the two effects is not possible given the available data.

${ }^{3}$ Research on the welfare cost of business cycles and the importance of uninsurable labor market risk includes Imrohoroglu (1989) and Beaudry and Pages (2001).

${ }^{4}$ The above distinction harkens back to the old saying that "The Great Depression wasn't so bad if you already had a job."

${ }^{5}$ The use of local labor markets, sometimes called commuting zones, as units of observations has been employed by Autor, Dorn and Hanson (2013), Chetty et al. (2014) and Tolbert and Sizer (1996), among others.

${ }^{6}$ Interestingly, Boone, Dube and Kaplan (2014), examining county level data, find "no relationship between the amount awarded and the severity of the downturn in the local economy." 
documentation and our justification for our exogeneity assumption appear in the Appendix.

For example, the Capital Transit Assistance program allocated roughly $\$ 6$ billion to fund public transit capital improvements to urbanized areas (UZAs). The apportionment for medium sized UZAs was determined by population density and population, and the apportionment for large UZAs (populations greater than 200,000) was determined by factors such as bus revenue vehicle miles, bus passenger miles, fixed guideway route (such as rail) miles and population density. From this, we conclude that the Capital Transit Assistance program dollars were not assigned to systematically better or worse off local labor markets. In Section 2 we expand on this and another example.

Our benchmark empirical finding can be stated as follows: $\$ 1$ million in Recovery Act spending within a local labor market increased employment locally by 9.53 persons and the wage bill by $\$ 1.02$ million according to our point estimates. ${ }^{7}$ To quantitatively decompose the increase in the wage bill into the intensive versus extensive margin we assume that, at the extensive margin (i.e. saved and created jobs), workers were paid the typical compensation to a full-time employee in the economy overall. We calculate this value to equal $\$ 47,400$ in 2009 , which implies extensive margin payments equal to $\$ 454,000$ with the remaining being intensive margin payments equaling $\$ 569,000$. This estimate is statistically different from zero at a $95 \%$ level, although we cannot rule out a larger or smaller intensive margin effect in light of our standard errors.

Our benchmark specification is population weighted, since there are large size differences among the labor markets and also there may be size-contingent effects of spending which our econometric model does not account for. For robustness, we also report unweighted estimates where we continue to find a large intensive margin effect, equal to $\$ 439,000$. However, for this alternative specification, the magnitudes of the employment and wage bill effects are larger relative to the benchmark specification. $^{8}$

In our paper's theory section, we construct a model to highlight a theoretical mechanism through which government spending shocks can lead to movements along both the intensive and extensive margins. In our model, a firm can meet the demand for goods by either hiring new employees and/or by altering the number of hours existing employees work. Changes along both these margins are costly. The firm incurs a cost to hire and fire workers when adjusting along the employment margin, and it faces an overtime premium when adjusting the number of hours existing employees work. The presence of these convex costs along the two margins causes the firm to optimally adjust along both margins to minimize the cost of producing the additional goods demanded by the government.

Next, to quantitatively assess the mechanism, we calibrate our model to data from the highway, bridge and street construction industry and then study the effect of government spending shocks consistent with Recovery Act data. Our model predicts that it costs the government approximately

\footnotetext{
${ }^{7}$ Importantly, one cannot interpret our estimates as measures of a "national jobs effect" because of potential cross-region spillovers, such as those resulting from common monetary policies or trade across local markets. For a discussion of the spillover from a common monetary policy, see Nakamura and Steinsson (2013).

${ }^{8}$ The differences between weighted and unweighted estimates explains the differences in the employment and wage bill results between our paper and that of Dupor and McCrory (2015).
} 
$\$ 134.5$ thousand dollars to generate one additional job for one year that in the long run pays an annual wage of $\$ 51.4$ thousand. In the model roughly one-third of all government spending goes towards compensating non-labor inputs and two-third towards the wage bill for labor compensation. In turn, of the two-third going towards the wage bill, $63.3 \%$ goes towards hiring new workers (the extensive margin) and $36.7 \%$ towards increasing the hours for existing workers (intensive margin). These finding qualitatively match the results delivered by our instrumental variables estimation.

In addition to providing theoretical underpinnings to our empirical results, our model also allows us to perform counterfactual policy experiments. Our policy experiments provide insight into what types of government policy would lead to more job creation per dollar of government spending. We find that to increase the employment effect the government should target firms with a large number of employees that are earning a relatively low hourly wage. We also find that it is better for the government to target a small number of firms with large government spending allocations in place of a large number of firms with small government spending allocations. With respect to the structure of the government spending shock, we find that uncertainty about the magnitude of the government spending shock is helpful and both very short and long duration shocks create the most employment.

Finally, in addition to empirically estimating and constructing a theoretical model to explore the difference between the extensive and intensive margin effects, we also present qualitative evidence in the form of survey responses from Recovery Act recipients that illustrate how a portion of the labor payments went toward adjustment along the intensive margin.

Our paper relates to two distinct lines of research. First, several studies have used cross-state comparisons of Recovery Act spending and employment outcomes using instrumental variables. Wilson (2012) uses formulary instructions for grant distributions to state governments as instruments to identify the effect of the act's spending component on employment. He finds that increasing employment by one worker at the one-year mark of the act cost $\$ 125,000$. Conley and Dupor (2013) use the grant amounts from the act's highway component as an instrument to identify the effect of act's spending on employment. They find that, over the first two years following the act's passage, it cost $\$ 202,000$ to create a job lasting one year. Chodorow-Reich et al. (2012) estimate the effect of the act's emergency Medicaid support to state government component using the pre-Act distribution of funds as an instrument. They find that during the first 18 months of the program, this component of the act increased employment at a cost of $\$ 26,000$ per job-year. ${ }^{9}$

In addition, Feiveson (2015) studies the impact of a federal intergovernmental revenue sharing program. She finds that that intergovernmental grants increase local spending and that sub-national governments with pro-government collective bargaining spend a larger fraction of their grants on increased wages of existing workers than those without the collective bargaining.

The second part of our paper ties our work to research on micro-level intensive and extensive

\footnotetext{
${ }^{9}$ Dube, Kaplan and Zipperer (2015), Dupor and McCrory (2015) and Feyrer and Sacerdote (2012) also follow this general methodology to assess the impact of the Recovery Act.
} 
adjustments of labor inputs. Papers along this line include Caballero, Engel and Haltiwanger (1997), Cooper, Haltiwanger and Willis (2004) and Cooper and Willis (2009). ${ }^{10}$ These papers are interested in building models that are simultaneously able to match the macro- and micro-level dynamics of labor demand and not directly to assess the effect of government policies.

\section{Empirical Analysis}

\subsection{The Data}

\section{The Sample}

Our unit of observation is a local labor market. Each local labor market is a, possibly singleton, set of counties that have substantial cross-county commuting patterns. We use the 2000 Census Journey to Work survey to measure commuter flows, measuring closeness between counties in terms of the fraction of the labor force pairs of counties that commute between each other. Then we use agglomerative hierarchical clustering to group these counties into local labor markets. Other applications of the commuting zone approach include Autor, Dorn and Hanson (2013) and Chetty et al. (2014).

Our methodology follows Tolbert and Sizer (1996) closely, with the main difference being that we use commuting data that has become available more recently. Our procedure returns 1293 local labor markets. The majority of markets consist of between 2 and 4 counties. We drop markets populations less than 25,000. This leaves us with 918 markets in our sample.

Summary statistics for our analysis appear in Table 1.

Outcome Variables ( $\Delta$ Job-Years and $\Delta$ Wage bill)

We use two employment outcome variables. Both are constructed using data from the Quarterly Wage Employment and Compensation Survey.

Our first outcome variable is the average change in employment from the base of 2008:Q4 over the following 8 quarters. Let $Y_{j, k}$ denote employment in market $j$ in quarter $k$.

$$
\Delta \text { Job-years }_{j}=\frac{1}{4 \times \operatorname{Pop}_{j}} \sum_{k \in K}\left(Y_{j, k}-\bar{Y}_{j}\right)
$$

where $\Delta$ denotes "change in." In our benchmark specification, we let $K=\{2009$ Q1, ..,2010Q4 $\} . \bar{Y}_{j}$ equals the market $j$ employment in 2008Q4.

The $(1 / 4)$ term transforms the variable from job-quarters to job-years. We also scale by each market's 2010 population, denoted $\operatorname{Pop}_{j} .{ }^{11}$

\footnotetext{
${ }^{10}$ Other work on firm problems in the face of non-convex adjustment costs include Khan and Thomas (2008) and Rust (1987).

${ }^{11}$ We choose the 2010 population values because these are decennial Census counts and involve less extrapolation than non-decennial years; however, our results are insensitive to scaling by 2008 population (pre-Recovery Act) values.
} 
Table 1: Summary statistics

\begin{tabular}{lcccc}
\hline \hline & Mean & Stdev. & 10th perc. & 90th perc. \\
\hline Total spending, per capita & 404.802 & 333.027 & 163.869 & 683.848 \\
Instrument spending, per capita & 86.800 & 80.320 & 28.021 & 157.521 \\
Total Change in Job-Years, per capita & -0.026 & 0.023 & -0.049 & -0.002 \\
Total Change Quarterly Wages, per capita & -0.002 & 0.002 & -0.004 & -0.001 \\
Employment-Population Ratio & 0.385 & 0.078 & 0.285 & 0.489 \\
$\quad$ Q4-2008 & 0.388 & 0.079 & 0.287 & 0.495 \\
Q3-2008 & 0.380 & 0.076 & 0.285 & 0.481 \\
Q2-2008 & 0.385 & 0.078 & 0.288 & 0.490 \\
Q1-2008 & 0.387 & 0.077 & 0.289 & 0.492 \\
Q4-2007 & 0.684 & 0.636 & 0.059 & 1.443 \\
Personal income (3-yr. moving average, & 177.809 & 935.807 & 17.518 & 325.299 \\
$\quad \Delta$ 2006-2008), thousands of \$ & 0.144 & 0.085 & 0.044 & 0.262 \\
Population per square mile/(1e+7) & 0.012 & 0.001 & 0.010 & 0.013 \\
Share of employment in manufacturing/100 & & & \\
Log of population/1000 & 0.003 & 0.001 & 0.002 & 0.005 \\
Wages-Population Ratio & 0.003 & 0.001 & 0.002 & 0.005 \\
$\quad$ Q4-2008 & 0.003 & 0.001 & 0.002 & 0.005 \\
Q3-2008 & 0.003 & 0.001 & 0.002 & 0.005 \\
Q2-2008 & 0.003 & 0.001 & 0.002 & 0.005 \\
$\quad$ Q1-2008 & & & & \\
$\quad$ Q4-2007 & & & & \\
\hline Total Expenditures = \$ 124 Billion & & & & \\
Instrument Expenditures = $\mathbf{~ 2 6 ~ B i l l i o n ~}$ & & & & \\
Number of Observations = 918 &
\end{tabular}

Notes: The unit of observation is a U.S. local labor market. We exclude markets with populations of less than $25,000$. Total and instrument spending data correspond to Recovery Act dollars through 2010:Q4. Total change variables are over the period from 2009:Q1 through 2010:Q4. 
Our second outcome variable is the accumulated change in the per capita wage bill in the first two years following passage, relative to a 2008:Q4 benchmark.

$$
\Delta \text { Wage } \text { bill }_{j}=\frac{1}{\operatorname{Pop}_{j}} \sum_{k \in K}\left(P_{j, k}-\bar{P}_{j}\right)
$$

where $P_{j, k}$ and $\bar{P}_{j}$ are the compensation amounts (in millions of dollars) to employees during the respective periods.

\section{Treatment Variable $\left(V_{j}\right)$}

First, we define $\tilde{V}_{j, k}$, as the Recovery Act dollars paid to organizations (i.e., non-federal government agencies, non-profit organizations and firms) within market $j$ cumulative through $k$ quarters since the Act's passage. Expenditures, or equivalently spending, are defined as dollars paid by the federal government to recipient organizations. These amounts are constructed using quarterly reports filed by recipients of contracts, grants and loans (CGLs) to the now defunct web site FederalReporting.gov. ${ }^{12}$

Federal agencies issuing the largest amounts of this form of aid included the Departments of Education, Health and Human Services, Transportation and Energy. This data gives us the zip code level of spending by specific CGL awardees, as well as their sub-recipients, vendors and sub-vendors.

The data are organized so that dollars are first obligated to prime recipients of awards and sub-recipient of awards. ${ }^{13}$ Each recipient organization reports both its award amount and a point of performance zip code. We use these zip codes to allocate award amounts to the various markets. This gives us a market-specific measure of total CGL awards, which forms the treatment.

The data also contains spending on vendors by the two types of recipients. Each vendor observation contains the following relevant information: a vendor name, an associated award number, a payment amount, and the zip code of the vendor's business headquarters. ${ }^{14}$

We scale by the labor market population and report values in millions of dollars,

$$
V_{j, k}=\frac{\tilde{V}_{j, k}}{(1 e+6) \times P o p_{j}}
$$

Finally, we set $k=2010$ Q 4 for every specification, and suppress the $k$ index in the remainder of the paper.

\footnotetext{
${ }^{12}$ After processing and data verification by the Recovery Accountability and Transparency Board, this data was posted on the web site Recovery.gov. A user's guide for this data is contained in Recovery Accountability and Transparency Board (2009).

${ }^{13}$ Our sample does not include sub-awards valued at less than $\$ 25,000$ because these recipients were not required to provide zip codes for these sub-awards. They totaled $\$ 5.74$ billion.

${ }^{14}$ Our sample does not include vendor and sub-vendor payments valued at $\$ 25,000$ or less because these recipients were not required to provide zip codes for these payments. They totaled $\$ 2.12$ billion. Our analysis requires one additional adjustment to the original data. Suppose an awardee in market $Q$ pays $\$ 30,000$ to a vendor headquartered in market $R$. This requires us to decrease the total aid amount to market $Q$ by $\$ 30,000$ and increase the total aid amount to market $R$ by $\$ 30,000$.
} 
Table 2: Components of the Recovery Act used in the construction of the instrument

\begin{tabular}{llc} 
Federal Department/Agency & Program Title & $\begin{array}{c}\text { Amount Authorized } \\
\text { (in billions) }\end{array}$ \\
\hline Environmental Protection Agency & State and Tribal Assistance Grants & 7.2 \\
General Services Administration & Public Building Fund & 5.6 \\
General Services Administration & Energy Efficient Federal Motor & 0.3 \\
& Vehicle Fleet Procurement & 12.2 \\
Department of Education & Special Education Fund & 16.5 \\
Department of Energy & Energy Efficiency and Renewable Energy & 2.7 \\
Department of Justice & Office of Justice Programs & 6.9 \\
Federal Transit Administration & Transit Capital Assistance & 2.1 \\
& (Urban and Non-Urban Programs) & 2.0 \\
U.S. Army Corp of Engineers & Civil Program Financing Only-Construction & \\
U.S. Army Corp of Engineers & Civil Program Financing & \\
\hline \hline
\end{tabular}

Note that not every component of the act is included in the treatment variable. The treatment does not include tax benefits to persons or firms, direct transfer payments from the federal government (e.g. social security transfers) or unemployment insurance benefits. ${ }^{15}$

\section{Instrument Variable $\left(V_{j}^{H}\right)$}

Since the allocation of the act's spending was perhaps in part endogenous with respect to local labor markets' economic conditions, we use instrumental variables to guard against potential endogeneity bias. We construct our instrument by first isolating the spending components of the act that were plausibly uncorrelated with the business cycle conditions specific to individual local labor markets.

We find these components by analyzing the act, federal codes and regulations cited by the act and guides written by federal agencies responsible for allocating Recovery Act dollars. The lack of correlation with the local business cycle occurs because of the nature of the criterion these agencies used to allocate funds. Examples of these criterion included regional flood risk, violent crime statistics, bus passenger revenue, fixed guideway revenue vehicle miles, population density, presence of federal buildings needing restoration, urbanized-to-nonurbanized population ratio and the presence of inland and costal navigation. ${ }^{16}$

We define our instrument to be the sum of spending on these components in local labor market $j$. The component instrument spending was $\$ 87$ per person. Per capita spending, on average, tended to be somewhat higher in the Northeast and somewhat lower in the Southeast. Table 2 contains

\footnotetext{
${ }^{15}$ The included and excluded agencies are listed in the paper's Appendix.

${ }^{16}$ Another criteria used by some agencies in allocating dollars was population. In our econometric model, we scale variables by population. Therefore, if an agencies' Recovery Act dollars were allocated only according to population, the scaled dollars would provide no cross-sectional variation in our regression. Importantly, only a few of the 9 programs that are used to make up the component instrument have a substantial population-determined allocation rule.
} 
a list of these programs. The largest two are the Department of Energy's Energy Efficiency and Renewable Energy initiative ( $\$ 16.5$ billion) and the Department of Education's Special Education Fund ( $\$ 12.2$ billion).

Nearly every agency responsible for dispersing Recovery Act dollars provided at least one detailed plan describing the criteria by which funds would be allocated. Isolating programs for which monies were not allocated based on differences in local business cycle conditions requires some judgment calls in interpreting these documents. In this respect, our analysis is similar to studies using narrative approaches to isolate exogenous changes in macroeconomic policies, such as Ramey (2011) and Romer and Romer (2010).

Next, we provide support for our exogeneity assumption for two components of our instrument here and discuss the other components in the Appendix.

First, the act's Capital Transit Assistance component authorized $\$ 6.9$ billion in funding for public transit capital improvement, including money allocated to, for example, bus purchases and retrofitting, bus shelters, track rehabilitation and rail cars. Roughly $\$ 6$ billion of these funds were channeled directly to urbanized areas (UZAs) from the federal government based on apportionment formulas. According to the Federal Register (2009), "For UZAs with 50,000 to 199,999 in population, the formula is based solely on population and population density. For UZAs with populations of 200,000 and more, the formula is based on a combination of bus revenue vehicle miles, bus passenger miles, fixed guideway revenue vehicle miles, and fixed guideway route miles, as well as population and population density." Note that the amount of aid to each urbanized zone was not dependent on the degree of economic stress felt in the area. Nonurbanized area CTA accounts for $\$ 0.68$ billion of the program. These grants are made to the state governments and the apportionment formulas are computed based on the ratio of each state's nonurbanized population relative to the national urbanized population as well as the land mass of nonurbanized areas.

Since state governments are the applicants for the nonurbanized area funds, this introduces the potential for endogeneity bias of project selection at the state level. Note that there are no instructions for states to prefer locating projects in areas hit harder by the recession. Whether states themselves took it upon themselves to allocate the nonurbanized area funds to places hardest hit by the recession was not possible for us to discern from available documents. We do note that the nonurbanized program constitutes only a small part of the TCA.

Second, the Recovery Act provided the General Services Administration (GSA) with $\$ 5.857$ billion. Approximately $\$ 5.5$ billion was appropriated to the Federal Building Fund, to be used to construct and restore federal buildings. Another $\$ 300$ million was appropriated for the procurement of energy-efficient vehicles in the federal fleet. We use funding from these two components as summands in our instrument amount. General Services Administration (2009a) describes two key goals of its projects: (i) spending money quickly to stimulate the economy and create jobs, (ii) improve the environmental performance of federal assets. 
General Services Administration (2009a) states construction projects will take place in all 50 states, the District of Columbia and two U.S. territories. We found no statement that the project selection would be aimed at particular states or localities because they were hardest hit by the recession. ${ }^{17}$ For GSA projects, all decisions are made at the federal level; therefore, we do not have to consider potential endogeneity introduced by state government level allocation decisions.

Dupor and McCrory (2015), in a related paper, use this instrument to isolate exogenous differences in Recovery Act spending across local labor markets. While that paper's instrument is the same as the current paper, the focuses of the two papers differ. That paper estimates the spillover effects of spending that occur because of interconnections through commuter flows. Our paper avoids the spillover issue, which is the focus of Dupor and McCrory (2015), by defining regions at a sufficient level of aggregation such that the spillovers are subsumed into the own regions' effect of spending.

\section{Conditioning Variables}

\section{Common Controls}

We will simultaneously estimate equations for $\Delta$ Job-years and $\Delta$ Wage Bill. Both equations will have the following common control variables: eight Census region dummies, the share of employment in manufacturing, the natural log of the population, the population density and a constant. We also control for the pre-Act income level in each market using a 3-year moving average of annual personal income per capita (from 2006 to 2008).

The region dummies are intended to control for region-specific employment and wage trends. The manufacturing share is included with the recognition of secular decline in manufacturing nationwide, which likely influenced markets differently depending on their manufacturing intensity. We include both the log of population and population density both because these demographic variables help explain the behavior of the labor market, and also because they may help explain variation in aid across markets. We include personal income because several of the non-government spending components of the act, such as low income food assistance and an expanded earned income tax credit, were geared towards the lower part of the income distribution.

We also include the change in the local labor market's unemployment rate between January 2008 and January 2009. Although we construct our instrument so that it is orthogonal to local labor market conditions, we include the change in the unemployment rate to control for any remaining correlation between regional instrument spending and regional business cycle conditions in the first stage, as well as the variable's predictive power in the second stage.

Each equation also has its own separate set of controls.

Equation Specific Controls

Define $F(L)=\left[\begin{array}{llll}L, & L^{2}, & \ldots, & L^{5}\end{array}\right]$. For the $\Delta$ Job-years equation, the lag variables, $F\left(\frac{E m p}{\text { Pop }}\right)$, are included as additional conditioning variables. Here, $\frac{\mathrm{Emp}}{\mathrm{Pop}}$ is the employment-population ratio

\footnotetext{
${ }^{17}$ The GSA documents analyzed were General Services Administration (2009a), General Services Administration (2009b) and General Services Administration (2012).
} 
in 2008Q4. For the $\Delta$ Wage Bill equation, we include $F\left(\frac{\text { Wage Bill }}{\text { Pop }}\right)$. These variables should be predictive of the local labor markets' employment and wage bill trajectories.

To some readers, it might appear that least-squares would more suitable for our setup than instrumental variables. In particular, one alternative might be to run a least-squares regression of an outcome variable, e.g. the change in job-years, on the instrument expenditures, and interpret this as the causal impact of Recovery Act spending. However, this would lead to an upwardly biased estimate of the causal impact if the projection of total spending on instrument spending, i.e. the first stage in the corresponding IV procedure, resulted in a coefficient greater than one. Intuitively, if each $\$ 1$ of instrument spending was associated with $\$ 2$ of total spending, then the least-squaresbased estimate would overstate the causal impact by $50 \%$ because it would be underestimating the amount of Recovery Act aid actually provided. ${ }^{18}$

This is likely in our application because we may not have included all of the exogenous components of total spending in our construction of the instrument. In fact, the coefficient from the projection described above equals 2.13 under our benchmark specification.

\subsection{Estimation and Results}

Let $X_{1}=\left[V\right.$, Common Controls, $\left.F\left(\frac{E m p}{\text { Pop }}\right)\right] . X_{2}$ is identical to $X_{1}$ except we replace the lagged values of $F\left(\frac{E m p}{\text { Pop }}\right)$ with $F\left(\frac{\text { Wage Bill }}{\text { Pop }}\right)$. Next, $Z_{1}$ is identical to $X_{1}$ except we replace $V$ with $V^{H}$. Similarly, $Z_{2}$ is identical to $X_{2}$ except we replace $V$ with $V^{H}$. Define the error terms from the two equations to be

$$
\begin{aligned}
& \varepsilon_{1}=\Delta \text { Job-years }-X_{1} \beta_{1} \\
& \varepsilon_{2}=\Delta \text { Wage Bill }-X_{2} \beta_{2}
\end{aligned}
$$

We estimate the pair of equations by GMM, which in this case is similar to three stage instrumental variables (3SLS). System estimation via GMM permits us to test cross-equation restrictions on parameter estimates. In constructing the optimal GMM weighting matrix, we assume

$$
E\left[\left\{\begin{array}{c}
Z_{1} \varepsilon_{1} \\
Z_{2} \varepsilon_{2}
\end{array}\right\}\left\{\begin{array}{ll}
Z_{1}^{\prime} \varepsilon_{1} & Z_{2}^{\prime} \varepsilon_{2}
\end{array}\right\}\right]=\left\{\begin{array}{cc}
\sigma_{11} E\left(Z_{1} Z_{1}^{\prime}\right) & 0 \\
0 & \sigma_{22} E\left(Z_{2} Z_{2}^{\prime}\right)
\end{array}\right\}
$$

Thus, the cross-equation moment conditions are conditionally independent. Within each equation, we assume conditional homoskedasticity.

First, we assess instrument relevance by reporting the first-stage estimates from the 3SLS procedure. These coefficients are from the least squares estimates and appear in Table 3. There are separate columns corresponding to the job-year and wage-bill equations since the two differ

\footnotetext{
${ }^{18}$ See Angrist and Pischke (2009) for a general discussion of the issue.
} 
Table 3: First-stage estimates for the benchmark specification, regressions of total spending on instrument spending

\begin{tabular}{lcc}
\hline \hline & \multicolumn{2}{c}{ Total spending } \\
\cline { 2 - 3 } & $\begin{array}{c}\text { JY Equation } \\
\text { Coef./SE }\end{array}$ & $\begin{array}{c}\text { WB Equation } \\
\text { Coef./SE }\end{array}$ \\
\hline Composite instrument & $2.13^{* * *}$ & $2.09^{* * *}$ \\
spending (\$1 Million p.c.) & $(0.15)$ & $(0.15)$ \\
Manufacturing & $-0.04^{* *}$ & $-0.04^{* *}$ \\
share/100 & $(0.02)$ & $(0.02)$ \\
Income [3-yr moving & $-0.04^{* * *}$ & $-0.05^{* * *}$ \\
average] thousands of $\$$ & $(0.02)$ & $(0.02)$ \\
Change in & $-0.33^{* * *}$ & $-0.24^{* * *}$ \\
unemployment rate [1/08 to 1/09](/100) & $(0.10)$ & $(0.09)$ \\
Log of & -0.01 & $-0.02^{* *}$ \\
population/1000 & $(0.01)$ & $(0.01)$ \\
Population per & 0.01 & 0.09 \\
square mile/(1e+7) & $(0.02)$ & $(0.06)$ \\
\hline \hline $\mathrm{N}$ & 918 & 918 \\
Partial F-Statistic & 192.302 & 182.500 \\
$R^{2}$ & 0.359 & 0.364 \\
\hline
\end{tabular}

Notes: JY stands for "Job-years" and WB stands for "Wage Bill." Each specification also includes eight region dummies, five lags of the employment-population ratio or the wage bill per capita, and a constant. The estimates use population weighting. ${ }^{*} p<.1,{ }^{* *} p<.05,{ }^{* * *} p<.01$

as a result of their respective equation-specific controls. The coefficient on the instrument equals roughly 2.1 in each case. Thus, for every one dollar of instrument Recovery Act aid, approximately $\$ 1$ of additional aid was also uncorrelated with the error term. This may reflect the possibility that we took a conservative approach in our narrative procedure for selected federal agencies that gave "non-targeted" aid. In other words, other components of the Recovery Act (besides those we chose) were also distributed agnostically with respect to the regions local business cycle conditions. Finally, the partial $F$-statistics from the first-stage equations equal 192 and 183, respectively. The high values support the strong instrument assumption to which we appeal.

The first column of Table 4 contains the benchmark estimates of the effect of Recovery Act spending on job creation (i.e., $\Delta$ Job-years). The coefficient on spending equals 9.53 (S.E. = 3.08). This implies that $\$ 1$ million in Recovery Act funding increased employment by 9.53 jobs of duration equal to one year.

The second column of Table 4 contains the estimates of the wage-bill equation. The coefficient equals 1.02 (S.E. $=0.33)$. This implies that adding $\$ 1$ million of Recovery Act spending to a labor market resulted in $\$ 1.02$ million in additional wage payments in that market in the first two years following the act's passage.

Next, we will use the coefficients from the job-year and the wage bill estimates to decompose 
the wage bill effect into wage payments to jobs created/saved and existing workers whose employment status was not affected by the act. To do this decomposition, we must take a stand on the compensation earned on a job either created or saved as a result of the act. We assume that the annual wage payment to a hired worker, resulting from the Recovery Act, equals $\$ 47,400$. This amount is roughly equal to the typical compensation to a full-time worker in the U.S. in 2009. We compute this number based on the following evidence. According to the 2009 Occupational Employment Statistics, the median hourly wage was $\$ 15.95$ in 2009 . According to the Current Employment Statistics, the median hours worked per week in 2009 was 40. The Employer Cost for Employee Compensation reported that wages accounted for $70 \%$ of total compensation. Given a 52 -week work year, this implies a typical annual employment compensation of roughly $\$ 47,400$.

Then, the wage payments to newly hired or retained workers, resulting from $\$ 1$ million of Recovery Act funding was approximately $\$ 451,000(=9.53 \times \$ 47,400)$. The payment to existing workers whose employment status did not depend on the act, in turn, equaled approximately $\$ 569,000$. This value is presented near the bottom of Table 4 in the row labeled "Intensive margin payments." Below this estimate, we report its $p$-value, which equals 0.046. Note that our intensive margin effect is estimated with some imprecision. Therefore, we cannot reject either a substantially smaller or substantially larger effect at conventional confidence levels.

In the next section, we study the explicit dynamic optimization problem of a firm that chooses whether to meet government demand by employing new workers or alternatively increasing the hours of existing workers. The model is capable of qualitatively explaining the above empirical finding.

For comparison, Table 5 provides the seemingly unrelated regression estimates corresponding to the benchmark 3SLS specification except all of the variables are treated as exogenous. This specification is analogous to a least-squares counterpart of the benchmark model, except that we allow for covariation of the two alternative treatment parameter estimates.

There are two key features of Table 5. First, the SUR coefficients are estimated more precisely relative to the 3SLS, as one would expect. Second, using the instrument, moving from Table 5 to Table 4 has little effect on the estimates of Recovery Act effect. This suggests that the endogeneity of spending caused little bias in the least-squares estimates, which is consistent with the Boone, Dube and Kaplan (2014) finding that spending was not systematically targeted to regions with severe local downturns.

Table 6 provides a number of alternative specifications. First, we report the benchmark estimates and then each column that follows contains a variant on the benchmark specification. The column labeled "unweighted" uses the benchmark specification except the error terms are not weighted by population. The job-years effect is substantially larger and the wage-bill effect is somewhat larger. This suggests that there is a significant size effect from stimulus: job creation/savings may tend to be larger in small local labor markets than in large ones. This feature merits further 
Table 4: 3SLS estimates of the effect on labor market outcomes of Recovery Act spending, benchmark specification.

\begin{tabular}{|c|c|c|}
\hline & \multicolumn{2}{|c|}{ Benchmark Specification } \\
\hline & $\begin{array}{l}\text { JY Change } \\
\text { Coef./SE }\end{array}$ & $\begin{array}{l}\text { WB Change } \\
\text { Coef./SE }\end{array}$ \\
\hline Direct ARRA spending & $9.53^{* * *}$ & $1.02^{* * *}$ \\
\hline (\$1 million p.c.) & $(3.08)$ & $(0.33)$ \\
\hline Manufacturing & $-3.50^{* * *}$ & -0.01 \\
\hline share/100 & $(0.81)$ & $(0.09)$ \\
\hline Income [3-yr moving & $-2.12^{* * *}$ & $0.14^{*}$ \\
\hline average] thousands of $\$$ & $(0.73)$ & $(0.08)$ \\
\hline $\begin{array}{l}\text { Change in } \\
\text { unemployment rate }[1 / 08 \text { to } 1 / 09](/ 100)\end{array}$ & $\begin{array}{c}-29.60^{* * *} \\
(4.52)\end{array}$ & $\begin{array}{c}-2.52^{* * *} \\
(0.45)\end{array}$ \\
\hline $\begin{array}{l}\text { Log of } \\
\text { population } / 1000\end{array}$ & $\begin{array}{c}-0.95^{* * *} \\
(0.36)\end{array}$ & $\begin{array}{c}-0.26^{* * *} \\
(0.04)\end{array}$ \\
\hline $\begin{array}{l}\text { Population per } \\
\text { square mile/(1e+7) }\end{array}$ & $\begin{array}{c}3.59^{* * *} \\
(0.95)\end{array}$ & $\begin{array}{c}-0.68^{* * *} \\
(0.25)\end{array}$ \\
\hline \multicolumn{3}{|l|}{ Intensive Margin } \\
\hline $\begin{array}{l}\text { Payments } \\
\text { (Millions of } \$ \text { ) }\end{array}$ & 0.569 & \\
\hline P-Value & 0.046 & \\
\hline $\mathrm{N}$ & 918 & \\
\hline$R^{2}$ & 0.647 & 0.601 \\
\hline \multicolumn{3}{|l|}{ First Stage Results } \\
\hline Partial F-Statistic & 192.302 & \\
\hline$R^{2}, 1$ st Stage & 0.359 & \\
\hline
\end{tabular}

Notes: JY stands for "Job-years" and WB stands for "Wage Bill." Intensive margin payment = WB Change $0.0474 \times$ JY Change. Each specification also includes eight region dummies, five lags of the employment-population ratio or the wage bill per capita, and a constant. The estimates use population weighting. ${ }^{*} p<.1,{ }^{* *} p<.05,{ }^{* * *}$ $p<.01$ 
Table 5: SUR estimates of the effect on labor market outcomes of Recovery Act spending, benchmark specification except all regressors are treated as exogenous.

\begin{tabular}{|c|c|c|}
\hline & \multicolumn{2}{|c|}{ Benchmark Specification } \\
\hline & $\begin{array}{l}\text { JY Change } \\
\text { Coef./SE }\end{array}$ & $\begin{array}{l}\text { WB Change } \\
\text { Coef./SE }\end{array}$ \\
\hline Direct ARRA spending & $11.87^{* * *}$ & $0.93^{* * *}$ \\
\hline Manufacturing & $-3.31^{* * *}$ & $\begin{array}{l}(0.0) \\
-0.01\end{array}$ \\
\hline share/100 & $(0.78)$ & $(0.08)$ \\
\hline $\begin{array}{l}\text { Income }[3 \text {-yr moving } \\
\text { average] thousands of } \$\end{array}$ & $\begin{array}{c}-1.98^{* * *} \\
(0.71)\end{array}$ & $0.13^{*}$ \\
\hline $\begin{array}{l}\text { Change in } \\
\text { unemployment rate }[1 / 08 \text { to } 1 / 09](/ 100)\end{array}$ & $-28.67^{* * *}$ & $\begin{array}{l}-2.51^{* * *} \\
(0.44)\end{array}$ \\
\hline $\begin{array}{l}\text { Log of } \\
\text { population/1000 }\end{array}$ & $\begin{array}{c}-0.88^{* *} \\
(0.35)\end{array}$ & $-0.27^{* * *}$ \\
\hline $\begin{array}{l}\text { Population per } \\
\text { square mile/ }(1 \mathrm{e}+7)\end{array}$ & $\begin{array}{c}3.62^{* * *} \\
(0.95)\end{array}$ & $\begin{array}{c}-0.68^{* * *} \\
(0.25)\end{array}$ \\
\hline Intensive Margin & & \\
\hline $\begin{array}{l}\text { Payments } \\
\text { (Millions of } \$ \text { ) }\end{array}$ & 0.372 & \\
\hline P-Value & 0.002 & \\
\hline $\mathrm{N}$ & 918 & \\
\hline$R^{2}$ & 0.649 & 0.601 \\
\hline
\end{tabular}

Notes: JY stands for "Job-years" and WB stands for "Wage Bill." Intensive margin payment = WB Change $0.0474 \times$ JY Change. Each specification also includes eight Census region dummies, five lags of the employmentpopulation ratio or the wage bill per capita, and a constant. The estimates use population weighting. ${ }^{*} p<.1,{ }^{* *} p$ $<.05,{ }^{* * *} p<.01$ 
Table 6: 3SLS estimates of the effect on labor market outcomes of Recovery Act spending, alternative specifications.

\begin{tabular}{lcccc}
\hline \hline & Benchmark & Unweighted & $\begin{array}{c}\text { Unweighted } \\
\text { Low } \\
\text { Population } \\
\text { Coef./SE }\end{array}$ & $\begin{array}{c}\text { Unweighted } \\
\text { High } \\
\text { Population } \\
\text { Coef./SE }\end{array}$ \\
\hline Job-Years & $\begin{array}{c}9.53^{* * *} \\
(3.08)\end{array}$ & $\begin{array}{c}17.36^{* * *} \\
(4.51)\end{array}$ & $\begin{array}{c}31.53^{* * *} \\
(7.76)\end{array}$ & $\begin{array}{c}7.31 \\
(4.64)\end{array}$ \\
Wage Bill & $\begin{array}{c}1.02^{* * *} \\
(0.33)\end{array}$ & $\begin{array}{c}1.26^{* * *} \\
(0.32)\end{array}$ & $\begin{array}{c}1.81^{* * *} \\
(0.50)\end{array}$ & $\begin{array}{c}0.85^{* *} \\
(0.36)\end{array}$ \\
\hline $\begin{array}{l}\text { Intensive Margin } \\
\text { Payments } \\
\text { (Millions of } \$)\end{array}$ & 0.569 & 0.439 & 0.317 & 0.506 \\
P-Value & 0.046 & 0.072 & 0.394 & 0.070 \\
\hline $\mathrm{N}$ & 918 & 918 & 458 & 459 \\
\hline \hline
\end{tabular}

Notes: JY stands for "Job-years" and WB stands for "Wage Bill." Intensive margin payment = WB Change $0.0474 \times$ JY Change. Each specification includes all of the regressors from the benchmark case.

study. Nonetheless, the intensive margin effect remains substantial in the unweighted case. The intensive margin payment point estimate equals $\$ 439$ thousand and its $p$-value equals 0.072 .

The next two columns split the sample into above and below median population groups, and then contain the unweighted estimates. As suggested by the full-sample, unweighted estimates, there is a substantial difference in stimulus labor market effects between low population and high population regions. Note that $90 \%$ of the U.S. population lives in an above-median population region. Thus, from a public-policy perspective, it likely makes more sense to focus on the weighted regression results when assessing the effectiveness of stimulus. It is for this reason that we report the weighted estimates as the benchmark specification.

Next, we observe that several of the programs that make up the component instrument are closely tied to the construction industry. These are the EPA assistance grants, the GSA Public Building Fund, the Department of Energy home energy efficiency improvement program, the Capital Transit Assistance grants and a U.S. Army Corp of Engineers construction program. Together, these construction-related programs account for $63 \%$ of the authorized $\$ 75.5$ billion summed across all the component instrument programs. Naturally, one might expect the labor market effects estimated by our IV procedure to be particularly strong in that industry.

To this end, we next estimate the benchmark specification except we use construction-industry labor market variables rather that the corresponding economy-wide variables. The results appear in Table 7. The resulting job-years coefficient equals 2.32 and is statistically different from zero at the $1 \%$ level. This is a substantial number relative to the estimated total employment effect of 9.53. Together, these two estimates imply that $24 \%(=2.32 / 9.53)$ of the jobs created/saved by the Recovery Act occurred in the construction industry. In contrast, construction jobs made up only 
Table 7: 3SLS estimates of the effect on construction industry labor market outcomes of Recovery Act spending.

\begin{tabular}{lc}
\hline \hline & $\begin{array}{c}\text { Construction } \\
\text { Coef./SE }\end{array}$ \\
\hline Job-Years & $2.32^{* * *}$ \\
& $(0.86)$ \\
Wage Bill & $0.15^{* *}$ \\
& $(0.06)$ \\
\hline Intensive Margin & \\
Payments & 0.038 \\
(Millions of $\$)$ & \\
P-Value & 0.266 \\
\hline $\mathrm{N}$ & 918 \\
\hline \hline
\end{tabular}

Notes: JY stands for "Job-years" and WB stands for "Wage Bill." Intensive margin payment = WB Change $0.0474 \times$ JY Change. Each specification includes all of the regressors from the benchmark case.

Table 8: Share of wage bill paid at the intensive margin, at various horizons

\begin{tabular}{cccc}
\hline \hline Horizon (in quarters) & 5 & 8 & 11 \\
\hline $\begin{array}{c}\text { Intensive margin's share } \\
\text { of wage bill }\end{array}$ & 0.713 & 0.557 & 0.160 \\
\hline \hline
\end{tabular}

$4.8 \%$ of total employment in the quarter preceding the act's passage. Similarly, Table 7 shows that the wage bill estimate is positive, statistically significant and larger in magnitude than would be suggested by the industry's wage bill relative to the economy overall.

Next, we examine one dynamic aspect of the intensive margin effect. We estimate the econometric model at several different horizons. Specifically, we replace the treatment variable with spending over horizon $H$ and do likewise for the outcome variables (the change in job years and the change in the wage bill). For each $H$, we compute the fraction of the overall wage bill paid to workers at the intensive margin, i.e. those whose jobs status did not depend on Recovery Act funding. The results are presented in Table 8. At the 5-quarter horizon, $71 \%$ of the wage bill is paid at the intensive margin. As the horizon is extended, this percentage falls. At the 11-quarter horizon, only $16 \%$ of the wage bill is paid at the intensive margin. One explanation, which we explore using the economic model in next section, is that it is costly to hire new workers in the short run, which leads firms and other organizations to rely on increasing the hours of existing workers in order to meet the government demand for goods and services. 


\section{A Structural Model of a Highway Construction Firm}

In the next section, we build a dynamic model capable of explaining the intensive margin effect. Although the mechanism behind the intensive margin effect is straightforward, it is useful to conduct build and calibrate a full blown dynamic model for two reasons. First, by calibrating the model to moments, ${ }^{19}$ besides those from our IV estimates, and then showing that the calibrated model can roughly match our IV estimates, we establish some external validation for our econometric results. Second, we employ the calibrated model to conduct interesting policy counterfactuals that are not possible using the IV estimates alone.

\subsection{The Model}

We consider the following dynamic decision-theoretic model of the firm.

Our model firm minimizes the cost of producing goods and services to fulfill demand from the public sector. ${ }^{20}$ The firm's production, $y_{t}$, is given by:

$$
y_{t}=L_{t}^{\alpha} A^{1-\alpha}
$$

where $L_{t}$ gives the amount of labor inputs, in units of labor hours, and the parameter $A$ proxies for non-labor inputs into production, such as land or fixed capital. Also, $\alpha$ gives the labor share.

The firm can change the amount of labor hours by adjusting along both the intensive and extensive margins:

$$
L_{t}=e_{t} h_{t}
$$

where $e_{t}$ is the number of employees (i.e. the extensive margin) and $h_{t}$ is the number of average hours each employee works (i.e. the intensive margin). Consequently, the number of employees and the average hours per employee jointly determine the firm's output and costs.

Next, the firm's per period cost function is:

$$
C\left(e_{t}, e_{t-1}, h_{t}, \psi_{t}\right)=w\left(h_{t}\right) e_{t}+\psi_{t}\left|e_{t}-e_{t-1}\right| \text { with } \psi_{t} \sim \text { i.i.d } U(0,2 \bar{\psi})
$$

with

$$
w(h)=w_{0}+w_{1} h^{2}
$$

The cost function has two components. The first component, $w\left(h_{t}\right) e_{t}$, is the total wage bill with the function $w\left(h_{t}\right)$ giving the average per employee wage. As seen in (3.4), the average per employee

\footnotetext{
${ }^{19}$ Moments that we will match include stimulus contracts of and the number of employees in a typical firm

${ }^{20}$ See Caballero and Engel (1993), Caballero, Engel and Haltiwanger (1997), Cooper, Haltiwanger and Willis (2004), Cooper and Willis (2009), and Bloom (2009) for similar models of the labor market.
} 
wage is a convex function of the average hours worked. The convexity assumption captures features like an overtime premium which results in the average per employee wage being a convex increasing function of the average number of hours worked by each employee. ${ }^{21,22}$

The second component in (3.4), $\psi_{t}\left|e_{t}-e_{t-1}\right|$, is the cost of hiring/firing. This component captures the cost a firm must pay when hiring or firing a worker and is in addition to the wage paid to this worker. We envision the stochastic hiring/firing cost, $\psi_{t}$, to umbrella all the costs associated with hiring/firing a worker. On the hiring side these costs include the cost of recruiting, the cost of training, the lost output due to low productivity of new hires, etc. On the firing side these costs include the loss of institutional knowledge and know-how when an employee leaves, the cost of severance, etc. The magnitude of these types of hiring/firing costs is time-varying and idiosyncratic to the match-quality of the employee. For example the loss due to low productivity of a new employee varies from new employee to new employee. Some new hires are highly skilled to begin with and there is very little lost productivity when they are hired, while others need time to adjust and acquire skills leading to extended periods of lost productivity. Similarly, the amount of institutional know-how varies from employee to employee, and thus losing some workers is much more costly than others.

Finally, for our baseline case, we study the firm's response to an unanticipated increase in government spending lasting $T$ quarters and starting in period 1:

$$
G_{t}=\left\{\begin{array}{cc}
\left(1+\gamma_{G}\right) \bar{G} & t \in[1, T] \\
\bar{G} & t>T
\end{array}\right.
$$

In Section 3.4, we explore other types of government spending shocks, including those with a stochastic aggregate component.

Formally, we can state the individual firm's cost minimization problem in recursive form with the following set of Bellman equations: ${ }^{23}$

$$
\mathscr{C}_{N}\left(e_{t-1} ; \psi_{t}\right)=\min _{e_{t}}\left\{C\left(e_{t}, e_{t-1}, h_{t} ; \psi_{t}\right)+\beta E\left[\mathscr{C}_{N}\left(e_{t} ; \psi_{t+1}\right)\right]\right\}
$$

s.t.

$$
\bar{G}=\left(e_{t} h_{t}\right)^{\alpha} A^{1-\alpha}
$$

and

\footnotetext{
${ }^{21}$ Do note that whereas the per employee wage is discontinuous in the number of hours worked by an employee as he/she moves from part-time to full-time or full-time to overtime, these discontinuities sufficiently smooth out into a convex function in the aggregate when considering the relationship between the average per employee wage and the average number of hours worked.

${ }^{22}$ Alternative formulations in the literature for the average per employee wage include $w(h)=w_{0}+w_{1} h^{\xi}$. For simplicity we set $\xi=2$ which is consistent with the range of estimates in Cooper and Willis (2009) of $\xi=1.78$ to 3.28

${ }^{23}$ Note that the functions $\mathscr{C}_{N}$ and $\mathscr{C}_{G}$ are not dependent on $t$. We include the time subscripts for ease of description.
} 


$$
\mathscr{C}_{G}\left(e_{t-1} ; \psi_{t}, \tau\right)=\left\{\begin{array}{cc}
\min _{e_{t}}\left\{C\left(e_{t}, e_{t-1}, h_{t} ; \psi_{t}\right)+\beta E\left[\mathscr{C}_{G}\left(e_{t} ; \psi_{t+1}, \tau-1\right)\right]\right\} & \text { if } \tau>0 \\
\mathscr{C}_{N}\left(e_{t} ; \psi_{t}\right) & \text { if } \tau=0
\end{array}\right.
$$

s.t.

$$
\left(1+\gamma_{G}\right) \bar{G}=\left(e_{t} h_{t}\right)^{\alpha} A^{1-\alpha}
$$

Here, $\mathscr{C}_{N}$ gives the Bellman equation for the periods when government spending is, and is expected to stay, at its steady state level. $\mathscr{C}_{G}$ is the Bellman equation for when the economy is experiencing increased government spending. The additional state variable $\tau$ in $\mathscr{C}_{G}$ gives the number of remaining periods of increased government spending.

For our baseline exercise, we assume that before period 1 the level of government spending was at its steady state level and that the firm expected this level to remain unchanged in the future. As such our firm's value function is given by $\mathscr{C}_{N}$ for periods before period 1 . The increase in government spending begins with setting the firms value function in period 1 at $\mathscr{C}_{G}$ with $\tau=T$, indicating that for the next $T$ periods, including the current period, the government spending will increase to $\left(1+\gamma_{G}\right) \bar{G}$. Note that in period $T$ the state variable $\tau$ will reduce to $\tau=0$, and thus in period $T+1$ the firm will reverts back to $\mathscr{C}_{N}$ as the value function for all the remaining periods.

\subsection{Calibration}

We calibrate our model to match establishment level facts from the U.S. highway, street and bridge construction industry. Besides making up a significant component of Recovery Act government spending, this sector has the richest available data from which to construct the calibration.

Table 9 presents all of the calibrated values.

We first set the quarterly discount factor, $\beta$, to be 0.99 . We next assume a labor share of 0.6 and a marginal cost markup of $33 \%$ resulting in $\alpha=0.45$. These are all standard values.

Next, we calibrate $A, w_{0}$ and $w_{1}$, such that the steady state hourly wage, average work week, and per establishment employment in the model match these variables for the highway, bridge and street construction industry in the data. From the Current Employment Statistics survey, we find that the average hourly wage in this industry was $\$ 23.8$ in 2008 and the sectoral average work week was 41.5, for a total of 539.5 hours per quarter. We then look to the U.S. Census Statistics of Businesses to determine the per establishment employment. In 2008 there were 11509 establishments in this sector with an industry-wide employment of 311,967 which implies an average employment of 27.1 workers per establishment.

To find the steady state level of government demand, G, we look to data from the Federal Highway Administration (FHWA). According to the FHWA, the total value of capital outlays paid for by government funds towards state administered highways (independent of the revenue source) 


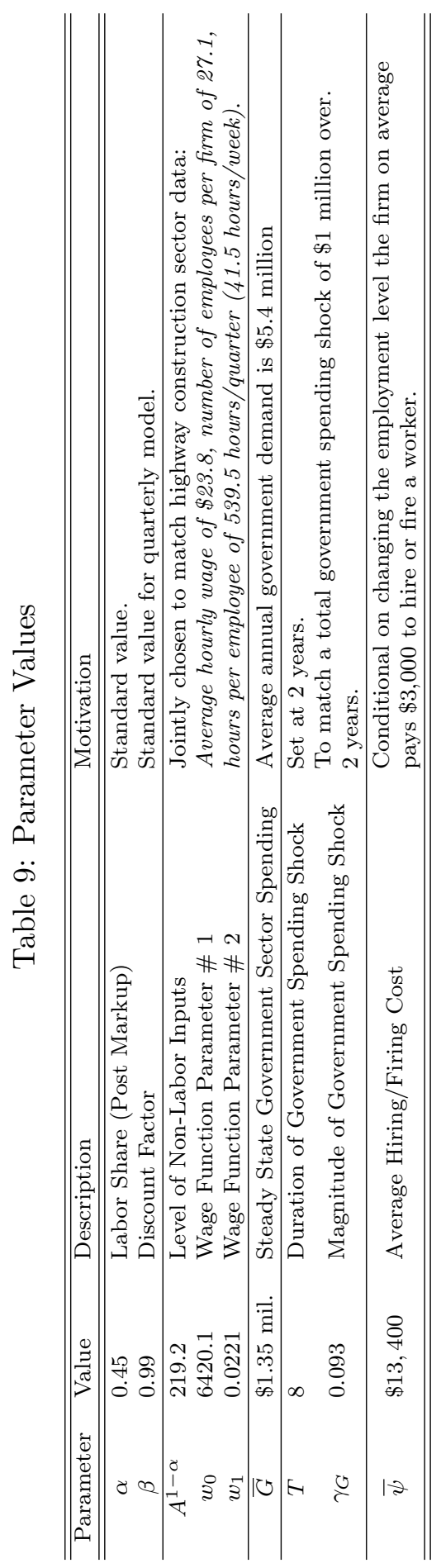


in 2007 was $\$ 62.5$ billion. Consequently, on average an establishment did $\frac{\$ 62.5 \text { billion }}{11509}=\$ 5.4$ million of business annually due to government demand, implying $\bar{G}=1.35$ million at the quarterly frequency.

To calibrate, $\gamma_{G}$, the size of the government spending shock to an average firm in the highway, bridge and street construction industry we turn our attention to the Recovery Act recipient reports. For every vendor with a contract of at least $\$ 25,000$, we know the vendors name, the cumulative amount billed by the vendor in each quarter as well as the federal agency that funded the project (for which the vendor was hired). For our analysis here we focus attention on spending from FHWA administered funds. The median size of such a contract was $\$ 1$ million. ${ }^{24}$ Spread over two year, $\mathrm{T}$ $=8$, this amounts to a shock of $\gamma_{G}=0.093$ per quarter.

Finally, we calibrate, $\bar{\psi}$ such that, conditional on hiring or firing an employee, the firms average hiring/firing cost is $\$ 3,000$ per hire or fire. This number is consistent with previous estimates in Dube, Freeman and Reich (2010) of hiring/firing costs that range from $\$ 2000$ for blue collar jobs to an economy-wide average of $\$ 4000$.

\subsection{Results}

Figure 1 plots the expected response of the firm to the increased government demand. In order to meet the additional government demand, the firm must increase the total number of labor hours. It can accomplish this increase by either hiring new employees and/or increasing the number of hours each employee works. Recall, adjustment along both these margins is costly. If the firm increases the number of employees it must pay hiring costs, while if it increases the number of hours each employee works the average per employee wage increases due to factors such as the overtime premium. Consequently, the optimal level of adjustment along these margins depends on the relative costs of adjusting along each margin. For our baseline calibration, the costs of increasing labor hours along both margins is convex, and thus, as seen in panels (b) and (c) of Figure 1, there is a partial adjustment along both margins - both employment and hours per employee rise in response to a government spending shock.

Our baseline results stand in stark contrast to an economy where there are no hiring/firing costs (plotted on the dotted line). In such an economy adjustment along the employment margin is costless and, as seen in panel (b) and (c) of Figure 1, the firm meets its additional labor hours demand by adjusting fully, and only, along the employment margin. Frictions in the hiring/firing process play an important role in explaining why firms adjust along both the employment margin and hours per employee margin. From a static perspective, positive hiring/firing costs cause hiring, similar to increasing hours, to be a costly process and as such this encourages the firm to use a optimal mixture of new employees and increased hours per employee to meet additional labor hours demand.

Next, from a dynamic perspective, the stochastic nature of hiring/firing costs causes the firm

\footnotetext{
${ }^{24}$ We choose to calibrate to the median vs. the average as there are many outliers
} 
to optimally wait to receive a sufficiently low cost draw before adjusting along the employment margin. In the interim while it waits for the low cost the firm can adjust along the hours margin to meet its labor hour demand. That is, if we view the stochastic hiring costs as proxying for match-quality, in order to meet new labor hours demand in the presence of hiring costs the firm in the short run optimally adjusts the average labor hours of existing workers while it waits to find a low costing new employee match to hire. These dynamic effects of hiring/firing costs can be seen in panel (d) where the extensive margin response to a government spending shock is gradual. For our baseline calibration there is a less than $50 \%$ chance of the firm hiring new employees in period of the government spending shock; however, the hiring does continue several quarters after the shock's arrival as the average firm continues to draw lower hiring costs.

The expected responses in Figure 1 can alternatively be viewed as giving an aggregate industry response. Under such an interpretation, the presence of stochastic hiring/firing costs further implies that adjustment along the employment margin at the industry-level will be gradual. This industrylevel gradual adjustment has two interesting features. As seen in panel (b) of Figure 1, the peak effect of government spending occurs a few periods before the end of the spending shock. Second, the effects of government spending on the employment margin, albeit small in magnitude, are felt for a number of periods following the end of the government spending shock. The stochastic nature of the hiring/firing costs explains both of these features.

First, because the firm can meet any shortfall in hours by adjusting along the intensive margin, the firm only adjusts along the employment margin when the stochastic costs are low. As a result, individual firms in the economy wait for a low hiring cost to hire new workers making the aggregate employment response to the shock gradual for the first few periods. Then, roughly mid-way through the shock, in anticipation of the end of the government spending shock, if an individual firm draws a low firing cost they fire workers causing employment to start gradually falling. This causes the peak response to the shock to occur in advance of the end of the shock. This shows how that job creation follows a hump shape, even though the government spending shock is spread uniformly over time.

Second, again due to the stochastic nature of the firing costs and the fact that any excess employment can be offset by adjusting along the intensive margin, some firms continue to keep excess employment well after the end of the shock. They keep the excess employment as they wait for a low enough firing cost to make it cost-effective for them to adjust downwards along the employment margin. This second result is interesting because it shows that the effects of government spending shocks on employment, even though very small, can be felt many years into the future through firms holding on to excess employees that they had originally hired to meet the increased government demand.

Finally, panel (e) of Figure 1 gives the cumulative effect of government spending on employment. Our baseline government spending shock of $\$ 1$ million uniformly distributed over 8 quarters 

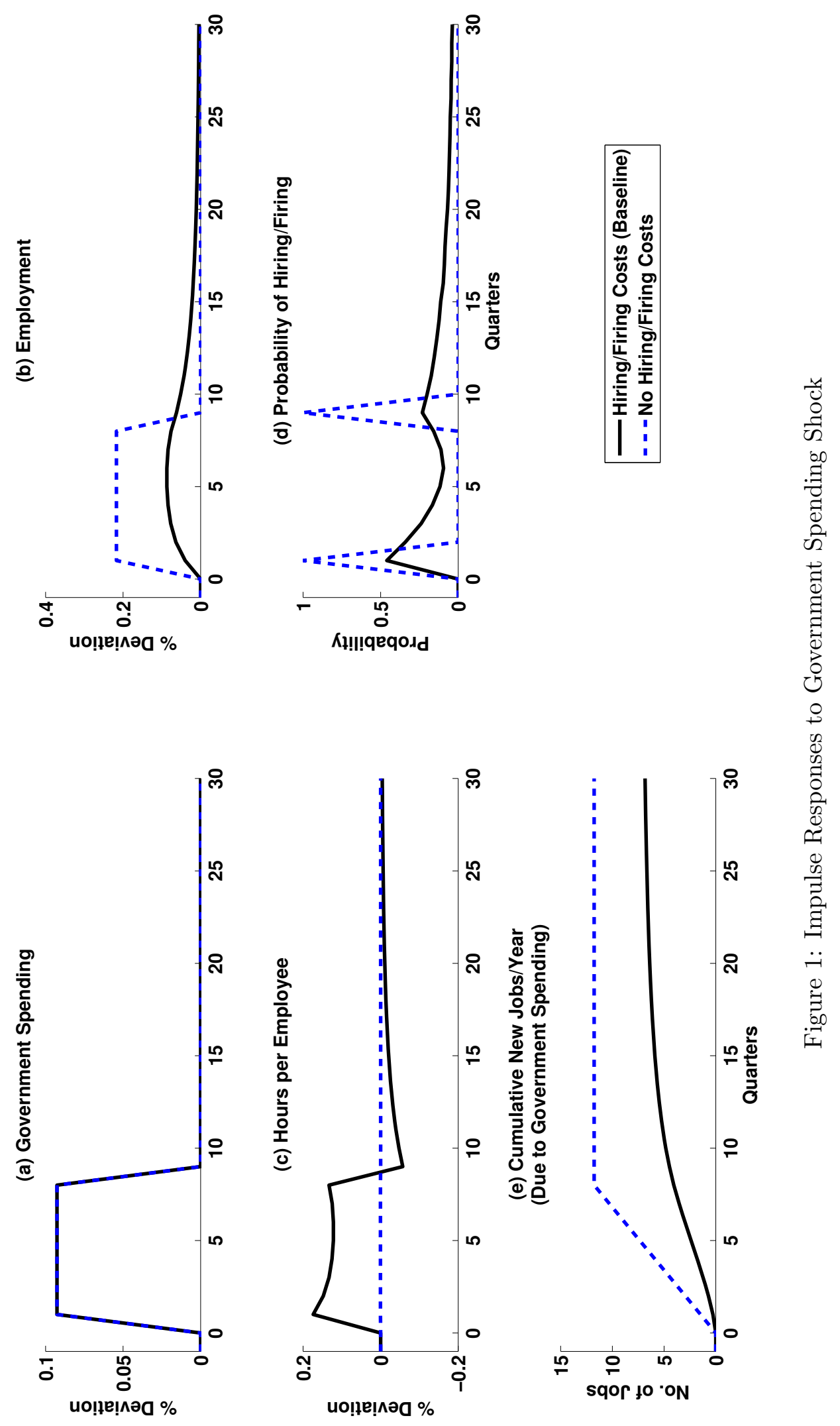
generates 7.4 new job years. This translates to approximately $\$ 134.5$ thousand in government spending per new job year created. This is in contrast to the calibrated per year steady state wage of $\$ 51.4$ thousand in the highway construction sector. In our theoretical model, similar to our empirical results, government spending does not directly translate dollar for dollar into new jobs. Our results show that the government will have to spend significantly more than $\$ 51.4$ thousand to generate a new job in this sector. There are two reasons for this. First, not all new labor spending goes towards creating new jobs. As discussed above, a significant fraction, of new labor spending, roughly $36.7 \%$ for our baseline calibration, goes towards increasing the labor hours of current employees due to the costs associated with the hiring/firing process. Second, the production of new goods requires a number of factors in addition to labor. As a result a non-trivial fraction of the revenue generated from new government spending, roughly $33.3 \%$ for our baseline calibration, goes towards compensating non-labor inputs, $A$, such as land. It should be noted that even though, our model does not measure such externalities, compensating non-labor inputs can generate jobs in other sectors. Our empirical estimate on the other hand do measure these externalities as long as the jobs are created in the same local labor market. We conjecture that these externalities are the main reason why our empirical estimates predict a 100\% pass-through of government spending to the wage bill versus our model that predicts an $66.6 \%$ pass-through.

Finally, the baseline entry of Table 10 quantitatively accounts for why a new job year costs $\$ 134.5$ thousand. The direct cost of hiring/firing a new worker and paying this worker one year's worth of wages is endogenously determined in the model to be approximately $\$ 56,700$. However, because only $63.3 \%$ of all labor spending goes towards hiring/firing new workers (i.e. the extensive margin), to hire this additional worker the firm must increase its labor spending by $\frac{\$ 56,700}{0.633} \approx \$ 89,600$. In turn, only $66.6 \%$ of the increased government spending translates into labor spending at the firm

level. Thus, the government must spend $\frac{\$ 89,600}{0.666} \approx \$ 134.5$ thousand to induce the firm to increase its labor spending by $\$ 89,600$ to hire one additional worker. In sum, the cost of one new job year is approximately $\$ 134.5$ thousand in government spending dollars and approximately $\$ 89.6$ thousand in wage bill (or labor spending) dollars. Our model predicts that roughly $57.8 \%$ of all government spending leaks to compensating non-labor inputs and adjustments along the intensive labor margin, in place of creating new jobs.

\subsection{Policy Implications}

In addition to providing a theoretical explanation of why government spending leads to movements along both the intensive and extensive margins, our model also provides a framework to conduct counterfactual policy exercises. In this section we use our model to shed light on how this government spending should be structured so as to attain the greatest amount of employment per dollar 
of spending. ${ }^{25}$

\section{Best Sectors to Target}

Recall that in the model new government expenditure, in addition to being spent on adjustments along the employment margin, is also spent towards payments along the intensive margin and to non-labor inputs. As a result, one can increase the employment effect of government spending by targeting sectors where there is less leakage of spending towards the intensive margin and nonlabor inputs. We find that to reduce the leakages to non-labor inputs the government should target sectors where a large fraction of sales is paid to labor and to reduce leakages towards the intensive margin we find that the government should target sectors with low hiring/firing costs.

In Table 10, we report the impact of a government spending shock as the number of employees at a firm increases. Holding the wage rate and total revenue from sales in steady state constant, as the number of employees increases, a larger fraction of the total steady state sales revenue goes towards compensating labor. In our baseline calibration, the total compensation for labor at $\$ 0.35$ million was approximately $26 \%$ of total sales. For our counterfactual cases, with 13.55 and 40.65 workers the labor compensation is approximately $13 \%$ and $39 \%$ of total sales respectively. As the fraction of labor compensation rises, the fraction of new government spending that goes towards compensating labor also increases. This in turn causes more money to be spent hiring new workers, lowering the dollar cost of each additional job. For our counterfactual exercise, holding the government spending shock constant at the baseline calibration, the cost of a new job-year falls three fold, from roughly $\$ 265.8$ thousand to $\$ 89.1$ thousand. This result indicates that if the government's goal is to increase employment then it should target firms and sectors that are labor intensive - firms and sectors where most of the sales revenue goes towards compensating labor.

There is an important caveat to the result above. If the increase in revenue going towards compensating labor results from higher wages, as opposed to larger employment, then the effects of government spending are not as large. For example, as wage increases from $\$ 11.9$ to $\$ 35.7$ holding the number of employees constant, similar to the previous exercise the total labor compensation goes from $13 \%$ to $39 \%$ of sales, however, as seen in Table 10 the effects on employment are much smaller than before. The reason for this is that when hourly wages increase the total per employee wage also increases. As a result, with higher wages, even though a higher fraction of sales revenue goes towards compensating labor, causing more of the new government spending to go towards compensating the labor, the higher cost of labor causes the new government spending to generate relatively fewer new jobs. This observation, coupled with the previous one, indicates that if the government's goal is to increase employment then it should target firms with a large number of employees that are earning relatively low hourly wages.

\footnotetext{
${ }^{25}$ For all the counterfactual exercises in this section, we recalibrate the values of $A, w_{0}, w_{1}$, and where indicated $\bar{G}, T$, and $\gamma_{G}$ as well. For example, in the exercises below involving a change in the wage rate, after setting the new wage rate we recalibrate the model to the baseline data moments except we use a counterfactual wage rate.
} 


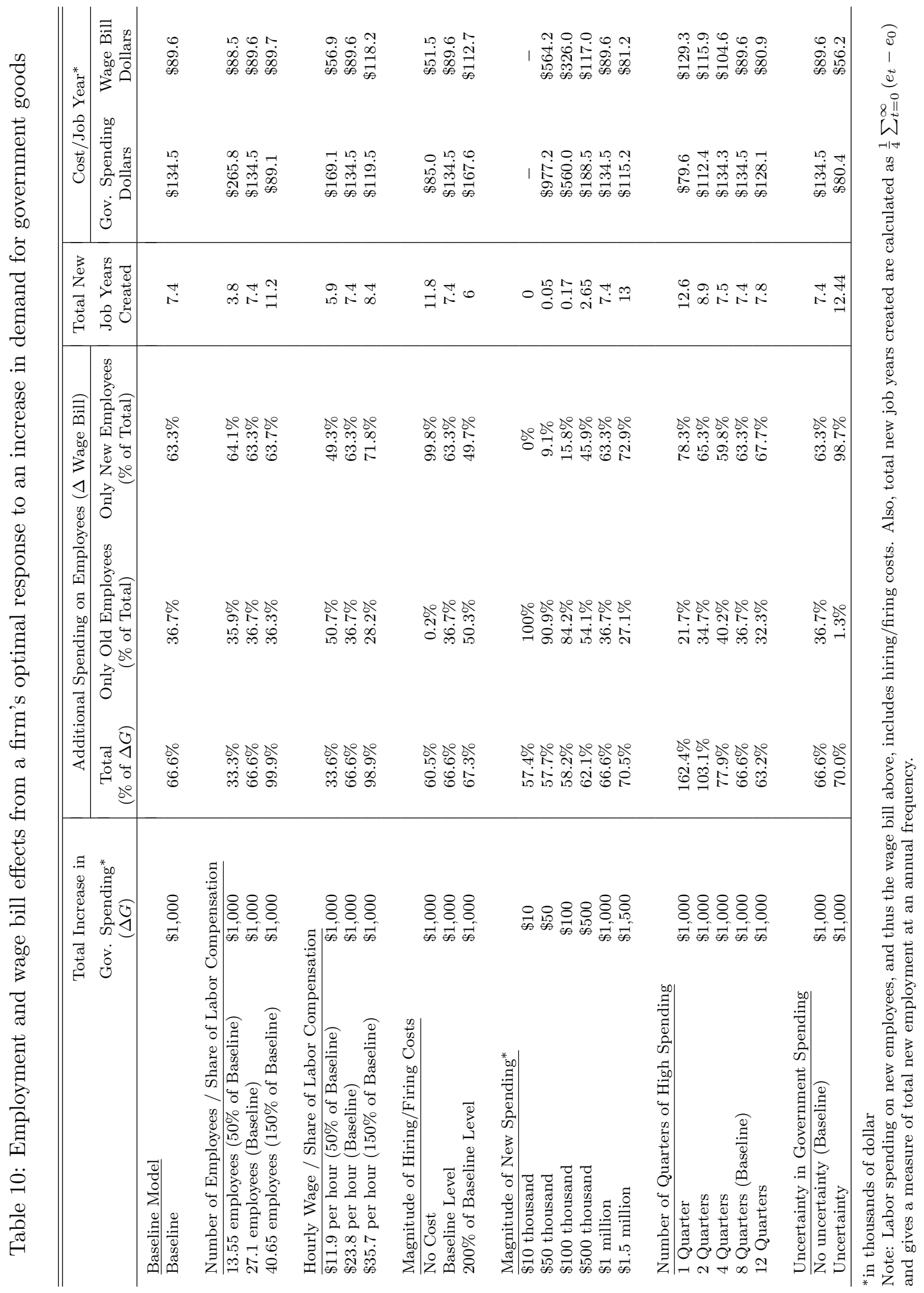


Next, under Magnitude of Hiring/Firing Costs in Table 10 we report how, in response to the baseline shock, the cost per job year changes as the magnitude of the hiring/firing costs change. As the magnitude of the hiring/firing cost increases, less and less of the new labor spending goes towards hiring new workers. This in turn causes the cost per job year in terms government spending dollars to rise. Larger hiring costs discourage the firm from hiring new workers to meet new labor hours demand, and the firm instead relies on adjustments along the intensive margin. These results suggest that government spending should target sectors where hiring/firing costs are low because lower costs will lead to greater adjustment by firms along the extensive margin. As calculated in Dube, Freeman and Reich (2010) blue collar jobs generally have lower hiring/firing costs when compared to professional or managerial jobs, thus indicating that sectors with a large fraction of blue collar jobs are good sectors to target in order to generate a large extensive margin effect.

\section{Structure of Government Spending Shock}

Next, we discuss how the structure of the shock, specifically the size, length, as well as whether the shock is random or deterministic, has important implications for job creation along the extensive margin.

We first vary the size of the spending shock. As seen in Table 10, when government spending increases by only $\$ 10$ thousand no new jobs are created. At $\$ 50$ thousand new jobs are created but at a very high cost of over $\$ 1$ million per job year. As the magnitude of spending shock increases to $\$ 1.5$ million, the cost of a new job falls to $\$ 115.2$ thousand per job year. The reason for this large difference in going from a small to large magnitude shock is twofold.

First, the hiring/firing cost introduces (S,s)-bound type non-linearities into the firm's employment decision. ${ }^{26}$ Figure 2 illustrates these non-linearities. Similar to a model with non-convex fixed costs, non-differentiable hiring/firing costs result in the firm having an $(\mathrm{S}, \mathrm{s})$ decision rule with an inaction region. As seen in the figure, for small deviations from the long run optimal employment level, $e^{*}$, the firm does not adjust its employment level. For such small deviations, the firm only adjusts the hours of existing workers. In our model, relatively small government spending shocks result in the firm deviating very little from its long run optimal level. As a result, for small shocks the firm mostly remains in the inaction region, thus exhibiting little to no adjustment in the total number of employees. Intuitively, the change in government spending is too small to induce the firm to pay the hiring cost to hire a new worker, and it thus optimally only adjusts along the intensive margin to meet the additional demand.

Second, the level of employment exhibits diminishing returns in the production function. Consequently, as the size of the spending shock rises the optimal level of employment increases at an increasing rate. Holding the level of labor hours per employee constant doubling the firm's output would require the firm to hire $2^{\frac{1}{\alpha}}(>2)$ as many workers. Therefore, the increase in the optimal

\footnotetext{
${ }^{26}$ The reason is that at $\left|e_{t}-e_{t-1}\right|=0$ these costs are not differentiable. At this point, the marginal cost of an infinitesimal change in employment is infinity causing these costs to act very much like standard fixed costs.
} 


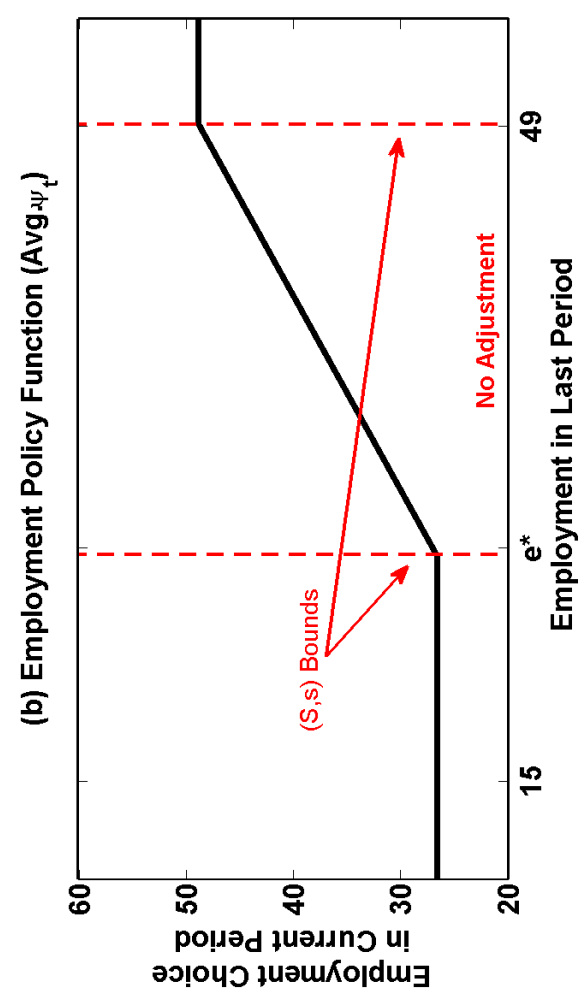

总

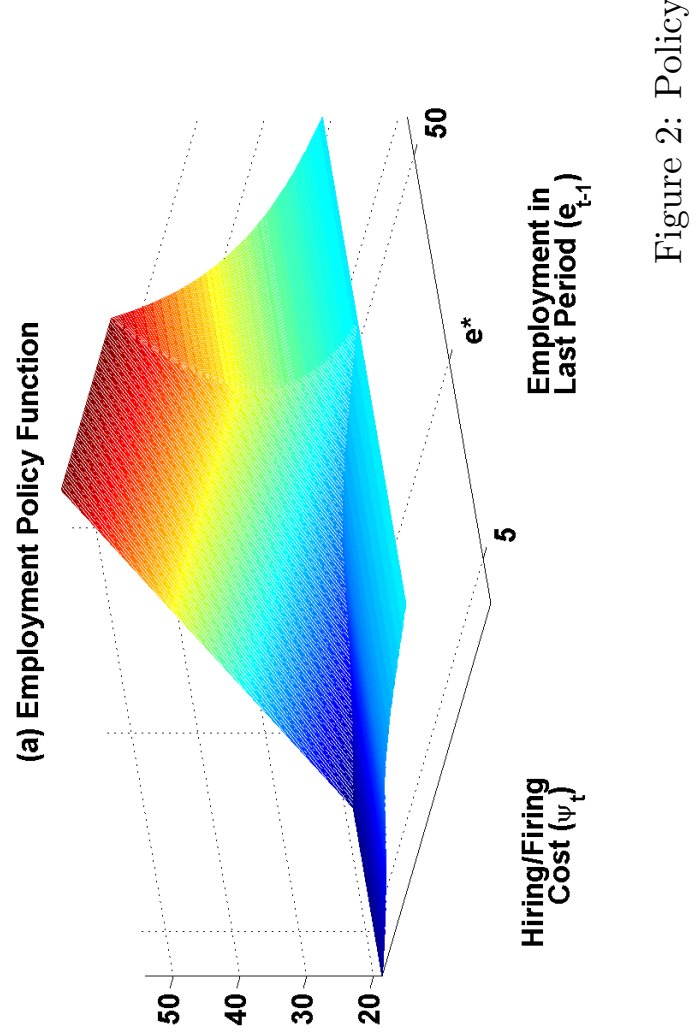

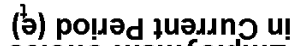

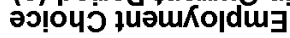


number of workers as the spending shock increases is also convex, causing the cost per new job to fall.

In sum, we find that as the magnitude of the government spending shock per firm increases, the cost of job creation falls. This suggests that, if the aim is to create the maximum number of new jobs, then for a fixed amount of stimulus money the government should target spending towards a small number of firms, as opposed to spreading the spending across many recipient firms.

Next, Table 10 shows how the number of new job years created varies as the duration of the government spending shock changes. In each case, the total spending over the duration is constant at $\$ 1$ million. The number of new jobs created first falls and then rises as the duration increases. The reason for this quadratic response is illustrated in Figure 3. When the government spending shock is short and sharp, the magnitude of the shock itself dwarfs the hiring cost causing the firm to not be hindered much by this friction. This results in a large increase in employment when the shock has a short duration.

In contrast, when the shock is spread out over a medium to large duration the hiring costs do matter. In particular, the presence of a stochastic hiring costs means that the longer the duration of the shock the higher the probability the firm draws a low hiring cost and adjusts along the employment margin. Consequently, when compared to medium duration shocks, large duration shocks generate more new job years.

These findings thus argue for government spending shocks to either be of a longer durations or be short and sharp. There are merits to both policies. As seen in panel (b) of Figure 3, shorter duration shocks have a larger peak employment response then longer duration shocks. Therefore, if the government's goal is a large short run employment boost then it should concentrate spending into a few quarters. Whereas, if the goal of the government is sustained long-term high employment, then a longer duration shock would be preferred.

Finally, we study how uncertainty about the government policy affects the cost per job year. To add uncertainty we replace equation (3.8) and (3.9) with

$$
\mathscr{C}_{G}\left(e_{t-1} ; \psi_{t}, \tau, G_{t}\right)=\left\{\begin{array}{cc}
\min _{e_{t}}\left\{C\left(e_{t}, e_{t-1}, h_{t} ; \psi_{t}\right)+\beta E\left[\mathscr{C}_{G}\left(e_{t} ; \psi_{t+1}, \tau-1, G_{t+1}\right)\right]\right\} & \text { if } \tau>0 \\
\mathscr{C}_{N}\left(e_{t} ; \psi_{t}\right) & \text { if } \tau=0
\end{array}\right.
$$

s.t.

$$
G_{t}+\bar{P}=\left(e_{t} h_{t}\right)^{\alpha} A^{1-\alpha}
$$

and add the following equation to the model 

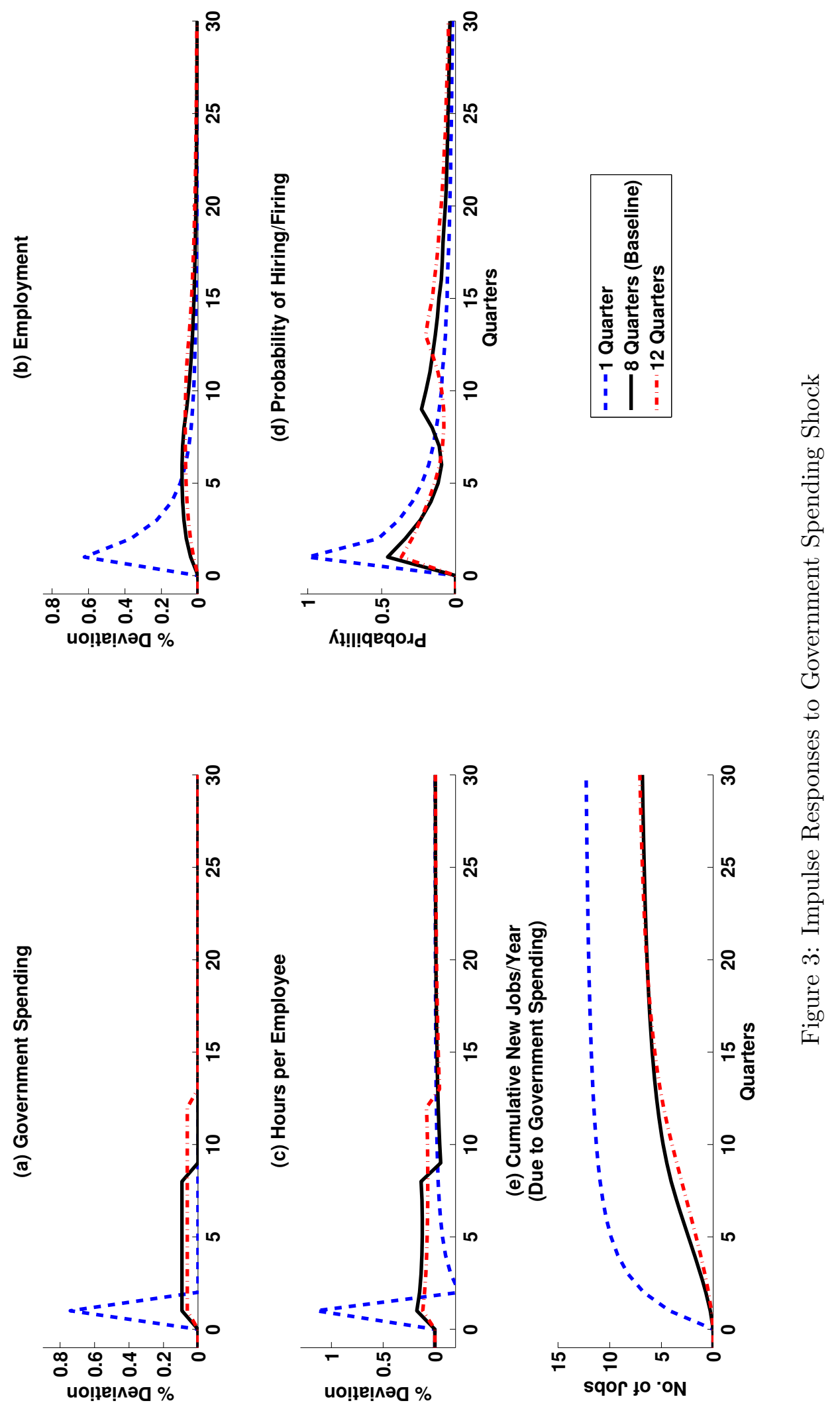


$$
G_{t}=\left\{\begin{array}{cc}
0.75\left(1+\gamma_{G}\right) \bar{G} & \text { with prob. } \frac{1}{3} \\
\left(1+\gamma_{G}\right) \bar{G} & \text { with prob. } \frac{1}{3} \\
1.25\left(1+\gamma_{G}\right) \bar{G} & \text { with prob. } \frac{1}{3}
\end{array}\right.
$$

In this new model, once the government shock arrives there is uncertainty about the magnitude of the government spending level, $G_{t}$.

To be consistent with our baseline exercises we assume that before period 1 the level of government spending was at its steady state level, and thus the firm's value function is still given by $\mathscr{C}_{N}$. We then assume that in period 1 there is an increase in government spending with the firm's value function now given by $\mathscr{C}_{G}$ and $G_{t}=\left(1+\gamma_{G}\right) \bar{G}$. Each subsequent period of the government spending shock there is a $1 / 3$ probability of each government spending level being equal to $0.75\left(1+\gamma_{G}\right) \bar{G}$, $\left(1+\gamma_{G}\right) \bar{G}$, and $1.25\left(1+\gamma_{G}\right) \bar{G}$. Finally, as in the baseline model, we assume that after $T=8$ periods, government spending returns to its steady state level and remains there with certainty.

Figure 4 plots the impulse responses for a simulation where the government spending shock, identical to the baseline calibration, has a realized value of $\left(1+\gamma_{G}\right) \bar{G}$ for each of the 8 quarters of the shock. As seen in panel (d), in the presence of uncertainty the firm is less likely to adjust along the employment margin as compared to the baseline case, but when it does adjust it hires many more workers. This on average results in a higher cumulative employment and lower cost per employee. The firm hires more employees because the level of employment exhibits diminishing returns in the production function, causing the optimal employment level to be convex in the size of the government spending. Consequently, per Jensen's inequality, when uncertainty about government spending increases, the optimal expected level of future employment needed also increases. ${ }^{27}$

Mathematically, if the optimal level of employment is $e^{*}$ for $\left(1+\gamma_{G}\right) \bar{G}, e_{L}^{*}$ for $0.75\left(1+\gamma_{G}\right) \bar{G}$, and $e_{H}^{*}$ for $1.25\left(1+\gamma_{G}\right) \bar{G}$. Then first we know that because of diminishing returns $e_{H}^{*}-e^{*}>e^{*}-e_{L}^{*}$. In turn, the expected employment optimal level next period if each of $0.75\left(1+\gamma_{G}\right) \bar{G},\left(1+\gamma_{G}\right) \bar{G}$, and $1.25\left(1+\gamma_{G}\right) \bar{G}$ is expected to occur with $1 / 3$ probability next period is $\frac{e_{H}^{*}+e^{*}+e_{L}^{*}}{3}>e^{*}$.

We find this result on uncertainty to be an interesting outcome of the diminishing returns structure of production. In particular, this result advocates for adding uncertainty to the government spending process in order to increase the extensive margin effect; in the presence of diminishing returns, the chance that the magnitude of government spending may be higher in the future induces the firms to hire more employees today.

\footnotetext{
${ }^{27}$ This result is often referred to as the Oi (1961), Hartman (1972), and Abel (1983) effect.
} 

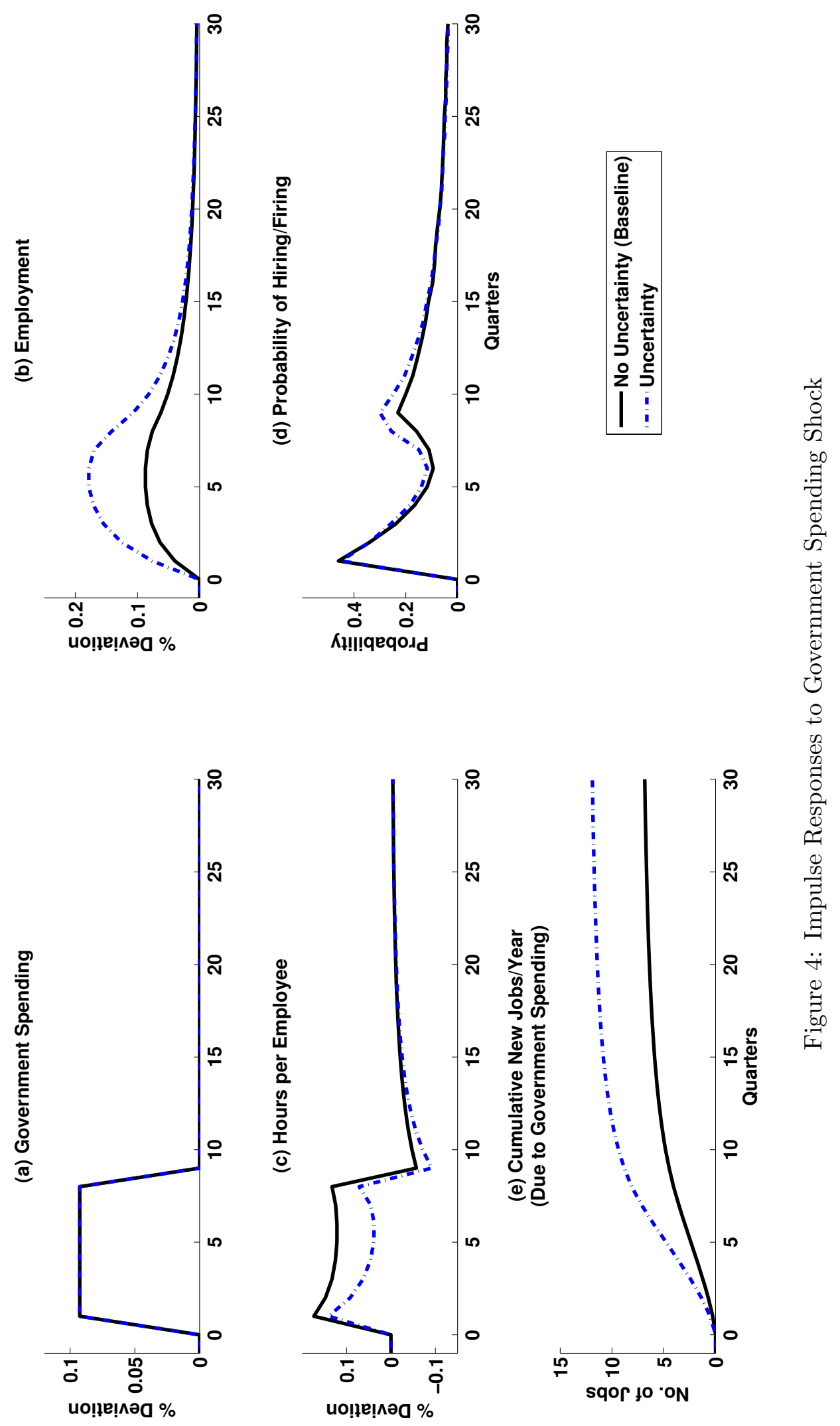


\section{Qualitative Evidence}

As demonstrated in the previous section, firms have incentive to meet the additional demand from government purchases by having existing workers take additional hours, in place of hiring new workers. The increase in hours implies that a portion of Recovery Act dollars were spent on labor but resulted in no additional workers hired; moreover, the cost of these additional hours is intensified if these workers are paid an overtime premium.

Dupor (2014) describes a novel component of the recipient reports used in Section 2 above. In that component, the survey responses contain qualitative descriptions of each project. The responses give hundreds of examples of projects being implemented using, at least in part, overtime workers. For example, a $\$ 26,000$ grant to a Wisconsin Indian Tribe administered by the Department of Justice explains that during 2011Q1: "This grant does not pay for additional jobs. It pays for overtime for the existing staff for community activities." As a second example, one part of a Recovery Act Department of Justice grant to the town of Barnsdale Oklahoma, during 2011Q1, was described as follows: "Jobs created were in the form of overtime paid to officers to work on specific quality of life activities." A grant to the Lyon County (Nevada) Sheriff's office, according to the recipient's report, had the following impact: "No jobs were created. Overtime was allotted for deputies to perform other duties." One recipient report from the city of Uniontown Pennsylvania stated simply that the labor demand impact of its grant was "payment of overtime for police officers."

Also, the survey responses contain many examples of Recovery Act grants being used for small increase in hours worked by existing employees, although they are not referred to explicitly as overtime work. For example, in a National Institute of Health grant to Emory University, aid was used to cover $10-15 \%$ of effort by each of three faculty investigators, $10-18 \%$ of the effort of a data analyst, a technical assistant and a training specialist. Two other Ph.Ds each expended $2 \%$ of their overall time on the project. Next, a trucking company working on a U.S. Forest Service contract reported that "Existing employees were utilized, but we were able to increase their hours of earnings per week." Along those same lines, another report stated: "We used our current workforce. This project did not create new positions nor were any existing employees retained due to the Recovery Act funded project."

In addition, the survey responses show that a portion of Recovery Act dollars were used for increased wage rates for existing workers. During 2011Q1, a $\$ 43,700$ grant to a Pennsylvania Child Services center as part of a Head Start program, was used in part to "Increase the compensation and benefits of staff through a $1.84 \%$ cost of living adjustment to improve the overall quality of

the program." As another example, one part of a grant to the Puerto Rico Department of Family was used to "to provide salary retention incentives" to employees. Another Head Start grant was, in part, described as follows: "Salaries were enhanced to ensure greater job satisfaction and staff retention." Hundreds of the Head Start programs across the U.S. used Recovery Act grants, in 
part, to fund similar cost-of-living increases.

Besides wage increases for existing workers, the survey responses also showed that Recovery Act dollars were used to fund pensions. As example, one grant recipient described "quality improvement funds used to increase qualified Head Start and Early Head Start staff fringe benefits, specifically 403B Pension contributions." Another recipient report stated that "A portion of the funding was used to cover a portion of the pension and health benefit costs for specific staff members identified in this area."

Increased payments to pensions likely led to little or no new job creation. Pension funding may have an additional Ricardian-equivalence type effect. Specifically, the federal government borrowed to fund the dollars that financed these Recovery Act programs, but pension financing effectively undid the borrowing by increasing private (albeit forced) savings.

The survey evidence described above gives qualitative evidence in support of the mechanism hypothesized early in the paper.

Note that other responses in the reports gives descriptions of job creation and retention at the extensive margin. For example, a New York state recipient of a U.S. Department of Energy Recovery Act grant reported the creation of 136 full-time equivalent jobs including 93 prime contractor and 43 sub-contractors full-time equivalent positions. As part of a weather modernization grant, the Sault Sainte Marie Tribe of Chippewa Indians reported that: "The Housing Authority recently hired a combination of carpenters and laborers totaling 28 new hires."

The descriptive information from the recipients also indicate many instances of jobs that were retained as a result of the act's funding. A New Jersey Head Start program reported that "Jobs retained include, teachers of preschool children and infants-toddlers, along with the teacher assistants" as a result of a Recovery Act grant. A California police department used a U.S. Department of Justice grant to avert the layoff of five of its officers. As another example, the Housing Authority of the City of Erie (Pennsylvania) reported that a Department of Housing and Urban Development grant it received resulted in 50 new hires and 24 layoffs avoided.

In addition to the job descriptions, the recipients were instructed to self-report how many fulltime equivalent (FTE) jobs were created/saved by the act. ${ }^{28}$ This reported figure includes both new jobs, saved jobs and increased hours for current workers. Of the roughly 100,000 prime awardees between 2009 and 2015, we find that roughly 19,000 recipients reported that zero FTEs where created/saved and roughly 15,000 reported that less than 1 FTE but more than zero FTEs were created/saved. Further, roughly 56,000 of the self-reported FTEs were fractional.

In summary, the survey responses give evidence that the Recovery Act led to important adjustments in labor along not only the extensive margin, but also the intensive margins.

\footnotetext{
${ }^{28}$ The full-time equivalent number of jobs equals the number of total hours worked divided by the number of hours in a full-time schedule.
} 


\section{Conclusion}

This paper makes three distinct contributions.

First, empirically the paper uses a new instrumental variable along with a quarterly panel of zip code level Recovery Act spending to measure the labor market effects of the Recovery Act. In particular, the paper is the first to distinguish, and measure, the effects of the Recovery Act on both the intensive and extensive labor margins. The paper finds that roughly $50 \%$ of all new labor spending created by the Recovery Act went towards payments to existing workers, in place of creating new jobs.

Second, on the theory side, the paper builds and calibrates a structural model of a firm that provides a microeconomic mechanism to explain our instrumental variable estimates. By its nature, the instrumental variables approach is limited in its ability to analyze the microeconomic mechanisms underlying our findings. Our model provides a theory based on overtime premiums and hiring/firing costs to explain why a significant portion of Recovery Act generated labor spending went towards the intensive margin. Our model also provides a framework to conduct counterfactual policy simulations, and thus, gives policy advice on what firms to target and how to structure government spending shocks so as to obtain a large employment effect.

Third, we use a narrative approach to provide qualitative evidence to support the presence of a significant intensive margin effect in response to the Recovery Act.

Finally, we note that our estimates of the employment effect maybe of limited use for understanding the aggregate effects of the act in the presence of cross-region spillovers. Sources of spillovers might include movements in factors of production, trade in goods or common monetary policy, among others. For example, if government purchases in state $X$ lead to inflows by some state $Y$ workers into state $X$, then there will be a negative spillover of spending in state $X$ on state $Y$. 


\section{References}

Abel, A. (1983), "Optimal Investment under Uncertainty," American Economic Review, 73, 228233.

Angrist, J. and J.-S. Pischke (2009)), Mostly Harmless Econometrics: An Empiricist's Companion.

Army Corp of Engineers, U.S. (2010a), "Civil Works Summary Agency Recovery Act Plan," March 31.

Army Corp of Engineers, U.S. (2010b), "Civil Works Program-Specific Agency Recovery Act Plan," March 31.

Autor, D., D. Dorn and G. Hanson (2013), "The China Syndrome: Local Labor Market Effects of Import Competition in the United States," American Economic Review, 103(6), 2121-68.

Beaudry, P. and C. Pages (2001), "The Cost of Business Cycles and the Stabilization Value of Unemployment Insurance," European Economic Review, 45, 1545-1572.

Bloom, N. (2009), "The Impact of Uncertainty Shocks," Econometrica, 77, 623-685.

Boone, C., A. Dube and E. Kaplan (2014), "The Political Economy of Discretionary Spending: Evidence from the American Recovery and Reinvestment Act," Brookings Papers on Economic Activity, Spring, 375-441.

Bradford, D. and W. Oates (1971), "The Analysis of Revenue Sharing in a New Approach to Collective Fiscal Decisions," Quarterly Journal of Economics, 85, 416-439.

Caballero, R. and E. Engel (1997), "Microeconomic Adjustment Hazards and Aggregate Dynamics," Quarterly Journal of Economics, 108, 359-383.

Caballero, R., E. Engel and J. Haltiwanger (1997), "Aggregate Employment Dynamics: Building From Microeconomic Evidence," American Economic Review, 87, 115-137.

Chetty, R., N. Hendren, P. Kline and E. Saez (2014), "Where is the Land of Opportunity? The Geography of Intergenerational Mobility in the United States," NBER Working Paper 19843.

Chodorow-Reich, G., L. Feiveson, Z. Liscow and W. Woolston (2012), "Does State Fiscal Relief During Recessions Increase Employment? Evidence from the American Recovery and Reinvestment Act," American Economic Journal: Economic Policy, 4(3),118-45.

Conley, T. and B. Dupor (2013), "The American Recovery and Reinvestment Act: Solely a Government Jobs Program?" Journal of Monetary Economics, 60, 535-549. 
Cooper, R., J. Haltiwanger and J. Willis (2004), "Dynamics of Labor Demand: Evidence from Plant-Level Observations and Aggregate Implications," NBER Working Paper 1029\%.

Cooper, R. and J. Willis (2009), "The Cost of Labor Adjustment: Inferences from the Gap," Review of Economic Dynamics, 12, 632-647.

Council of Economic Advisers (2009), "Estimates of Job Creation from the American Recovery and Reinvestment Act," Executive Office of the President of the United States, May.

Council of Economic Advisers (2014), "The Economic Impact of the American Recovery and Reinvestment Act Five Years Later," Executive Office of the President of the United States, February.

Dube, A., E. Freeman and M. Reich (2014), "Employee Replacement Costs," IRLE Working Paper 201-10.

Dube, A., E. Kaplan and B. Zipperer (2014), "Excess Capacity and Heterogeneity in the Fiscal Multiplier: Evidence from the Obama Stimulus Package," University of Maryland, working paper.

Dupor, B. and P. McCrory (2015), "A Cup Runneth Over: Fiscal Policy Spillovers from the 2009 Recovery Act," Federal Reserve Bank of St. Louis Working Paper 2014-029B.

Dupor, B. and M. S. Mehkari (2015), "Schools and Stimulus," Federal Reserve Bank of St. Louis Working Paper 2015-004A.

Dupor, B. (2014), "The 2009 Recovery Act: Directly Created and Saved Jobs Were Primarily in Government," Federal Reserve Bank of St. Louis Review, 96.

Education, U.S. Dept. of (2009), "Guidance: Funds for Part B of the Individuals with Disabilities Act Made Available under the American Recovery and Reinvestment Act of 2009," July 1, revised.

Energy, U.S. Dept. of (2009), "American Recovery and Reinvestment Act Program Plan for the Office of Energy Efficiency and Renewable Energy," May 15.

Energy, U.S. Dept. of (2010), "American Recovery and Reinvestment Act Program Plan for the Office of Energy Efficiency and Renewable Energy," June 15 (updated).

Environmental Protection Agency (2009), "Award of Capitalization Grants with Funds Appropriated by P.L. 111-5, the American Recovery and Reinvestment Act," Office of Water, March 2 .

Environmental Protection Agency (2011), "Implementation of the American Recovery and Reinvestment Act of 2009: Clean Water and Drinking Water State Revolving Fund Programs," Office of Water, May. 
Federal Register (2009), Federal Register 74 (42), Government Printing Office, 9656-9671.

Feiveson, L. (2015), "General Revenue Sharing and Public Sector Unions," Journal of Public Economics, $125,28-45$.

Feyrer, J. and B. Sacerdote (2012), "Did the Stimulus Stimulate? Effects of the American Recovery and Reinvestment Act," Dartmoth College.

General Services Administation (2009a), "American Recovery and Reinvestment Act Agency-Wide Recovery Plan."

General Services Administation (2009b), "GSA Motor Vehicle Replacement Plan: Energy Efficient Federal Motor Vehicle Fleet Procurement."

General Services Administation (2012), "Revised American Recovery and Reinvestment Plan \#10," U.S. GSA Public Building Services, November 30.

Hartman, R. (1972), "The Effect of Price and Cost Uncertainty on Investment," Journal of Economic Theory, 5, 258-266.

Imrohoroglu, A. (1989), "The Cost of Business Cycles with Indivisibilities and Liquidity Constraints," Journal of Political Economy, 97, 1364-1383.

Environmental Protenction Agency (2009a), "Office of Justice Programs Recovery Act Grants," Office of Justice Programs.

U.S. Department of Justice (2009b), "Recovery Act: Correctional Facilities on Tribal Lands Program Competitive Grant Announcement," Bureau of Justice Assistance, May 4.

Khan, A. and J. Thomas (2008), "Idiosyncratic Shocks and the Role of Nonconvexities in Plant and Aggregate Investment Dynamics," Econometrica, 76,395-436.

Nakamura, E. and J. Steinsson (2013), "Fiscal Stimulus in a Monetary Union: Evidence from U.S. Regions," American Economic Review, 104, 753-792.

New America Foundation (2014), "Individuals with Disabilities Education Act-Funding Distribution," Federal Education Budget Project, April.

Oi, W. (1961), "The Desirability of Price Instability Under Perfect Competition, " Econometrica, $29,58-64$.

Ramey, V. (2011), "Identifying Government Spending Shocks: It's All in the Timing," Quarterly Journal of Economics, 126, 1-50. 
Recovery Accountability and Transparency Board (2009), "Recovery.gov: Download Center Users Guide," Recovery.gov.

Romer, C. and D. Romer (2010), "The Macroeconomic Effects of Tax Changes: Estimates Based on a New Measure of Fiscal Shocks," American Economic Review, 100, 763-801.

Rust, J. (1987), "Optimal Replacement of GMC Bus Engines: An Empirical Model of Harold Zurcher," Econometrica, 55, 999-1033

Tolbert, C. and M. Sizer (1996), "U.S. Commuting Zones and Labor Market Areas," Economic Research Service, Rural Economy Division, U.S. Dept. of Agriculture, September.

Wilson, D. (2012), "Fiscal Spending Multipliers: Evidence from the 2009 American Recovery and Reinvestment Act," American Economic Journal: Economic Policy, 4, 251-282. 
Table A.1: Agencies and subagencies administering Recovery Act funds, inclusion or exclusion for this paper's data set.

\begin{tabular}{ll} 
Included & Excluded \\
\hline Agriculture, Dept. of & Federal Communications Commission \\
Army Corp of Engineers & Government Services Administration \\
Commerce, Dept. of & Labor, Dept. of \\
Corporation for National and Community Service & National Science Foundation \\
Defense, Dept. of & Small Business Administration \\
Education, Dept. of & Social Security Administration \\
Energy, Dept. of & State, Dept. of \\
Environmental Protection Agency & Railroad Retirement Board \\
Health and Human Services*, Dept. of & Interior, Dept. of \\
Housing and Urban Development, Dept. of & \\
Transportation, Dept. of & \\
Treasury, Dept. of & \\
\hline \hline
\end{tabular}

Notes: $(*)$ The emergency Medicaid state grants component of Dept. of Health and Human Services Recovery Act funds are excluded from the data set because they are not also available in the recipient reports.

\section{A Appendix (not for publication)}

\section{A.1 On the Data}

Here is a list of the agencies and subagencies responsible for administering Recovery Act funds.

The Dept. of Labor funds are excluded because these are primarily made up of direct transfers to individuals (though unemployment insurance benefits) and also are not subject to recipient reporting. The emergency Medicaid grant component of the Dept. of Health and Human Services funds Recovery Act funds are likewise excluded from the data. The Dept. of Social Security funds are excluded because these are primarily made up of direct transfers to individuals (entitled "economic recovery payments") and also are not subject to recipient reporting.

The remaining "Excluded" agencies make up a very small fraction of Recovery Act dollars. For nearly every agency, its reports showed that all or almost no funds were channeled through the states.

\section{A.2 Additional Instrument Construction Information}

In this section, we provide our reasons for including the various component of Recovery Act spending in our construction of the instrument. ${ }^{29}$

Environmental Protection Agency (EPA) State and Tribal Assistance Grants. The Recovery Act included $\$ 7.22$ billion for EPA projects. The largest programs were the State Revolving

\footnotetext{
${ }^{29}$ The information in this section of the appendix also appears as an appendix in Dupor and McCrory (2015).
} 
Fund Capitalization Grants to supplement the federal Clean Water State Revolving Fund and the Drinking Water State Revolving Fund, for which the act allocated $\$ 4$ and $\$ 2$ billion respectively. Since the capitalization grants were the lion's share of the EPA's entire stake in the Recovery Act, our discussion of the EPA's funding guidelines will be restricted to this program.

States prepared annual Intended Use Plans to describe how funds would be used. An administrative guidance, Environmental Protection Agency (2009), describes several of the criteria that states were to use in their own project selection. These include giving priority to projects that will be "ready to proceed to construction within 12 months of enactment of the Act," and having "not less than $20 \%$ of funds go to green projects." There were also "Buy American" requirements for iron, steel and manufactured goods incorporated into projects and Davis-Bacon wage rate restrictions. Nowhere in the guidances that we read or the legislation itself is there mention of states being directed to apply fund to areas hardest hit by the recession. ${ }^{30}$ Given the federal guidances, we argue that program administrators-at the state level-would put much greater concern towards putting money where water quality needs were greatest as opposed to attempting to use funds to combat low employment in particular counties within a state.

Department of Justice Office of Justice Programs (OJP). These grants were administered to state and local governments to support activities "to prevent and control crime and to improve the criminal justice system." 31 The program was authorized $\$ 2.7$ billion. Of this amount, $\$ 1.98$ billion was issue via formulary Justice Assistance Grants (JAG). Sixty percent of the JAG allocation was awarded to states with the remainder set aside for local governments. Formula dictating allocations are based on population and violent crime statistics. The formula also includes minimum allocation rules to prevent states and localities from receiving disproportionately low funds. The next three largest components of the OJP were for correctional facilities on tribal lands (\$225 million), grants to improve the functioning of the criminal justice system ( $\$ 125.3$ million) and rural law enforcement grants to combat crime and drugs $(\$ 123.8)$. All three were discretionary grants.

Nowhere in the program's documentation that we examined do we find instructions from the Department of Justice to have localities or states direct grant aid to those areas harder hit by the recession. For example, with respect to the correctional facilities on tribal lands grants, there are a number of restrictions (see Justice, Department of (2009b)). A few of these are "Buy American" provisions, Bacon-Davis wage requirements and preference for quick start activities. Serving areas hardest hit by the recession as an instruction to recipients or a criterion for receiving the grant is not among the restrictions. We conclude that the allocations of this component of the act were largely uncorrelated with the degree of economic weakness in the local labor markets that received this aid. other Recovery Act components that we include in the instrument.

Department of Energy (DOE). The Recovery Act authorized $\$ 16.51$ billion for 10 distinct

\footnotetext{
${ }^{30}$ These documents include Environmental Protection Agency (2009) and Environmental Protection Agency (2009).

${ }^{31}$ See Justice, Department of (2009a).
} 
Energy Efficiency and Renewable Energy (EERE) programs. According to U.S. Dept. of Energy (2009), EERE projects "will stimulate economic development, provide opportunities for new jobs in growing industries, and lay the foundation for a clean energy future." Moreover, "Over $\$ 11$ billion of EERE's Recovery Act funds will be used to weatherize homes of low-income Americans through the Weatherization Assistance Program (WAP) and will go to states and local communities through the State Energy Program (SEP) and Energy Efficiency and Conservation Block Grant Program (EECBG) to implement high priority energy efficiency projects."

The Recovery Act weatherization component, the largest of the EERE Recovery Act programs, totalled $\$ 4.98$ billion and were an add-on to the regular annual federal WAP. The Weatherization program state-by-state allocation formula is based on several factors: the low income population, climatic conditions and residential energy expenditures by low income households.

The Department of Energy EERE guidances concerning the Recovery Act do not discuss how states and localities should spend dollars in order to maximize support for areas hardest hit by the recession. $^{32}$

\section{Federal Transit Administration (FTA) Transit Capital Assistance (TCA).}

U.S. Army Corps of Engineers. First, the act provided $\$ 4.6$ billion allocated to the U.S. Army Corp of Engineers (USACE) Civil Financing Only program. It consisted primarily of two parts: Construction ( $\$ 2$ billion) and Operations and Maintenance ( $\$ 2.075$ billion). The spending was applied to improve categories such as inland and coastal navigation, environmental and flood risk management, hydropower and recreation. Besides general provisions applied to all components of Recovery Act funding, the Corp applied the following five additional criteria for project selection: (1) Be obligated quickly; (2) Result in high, immediate employment; (3) Have little schedule risk; (4) Be executed by contract or direct hire of temporary labor; and (5) Complete a project phase, a project, an element, or will provide a useful service that does not require additional funding (see U.S. Army Corp of Engineers (2010a)).

In two key agency Recovery Act plans, U.S. Army Corp of Engineers (2010a) and U.S. Army Corp of Engineers (2010b), there was little discussion of the USACE aiming funds towards areas that faced greater economic stress during the past recession. The only exception is that these planning documents mentioned in several places the USACE's desire to "support the overall purpose of ARRA to preserve and create jobs and promote economic recovery; to assist those impacted by the recession; and to provide investments needed to increase economic efficiency." Otherwise, there was no discussion of the USACE aiming targeting project funds to the worst hit areas. Also, there was no specific discussion of how the desire to assist those most impacted by the recession was operationalized in the USACE's plans. Finally, all USACE project decisions were made at the federal level; therefore, there was no potential endogeneity introduced by state government level allocation decisions.

\footnotetext{
${ }^{32}$ See U.S. Dept. of Energy (2009) and U.S. Dept. of Energy (2010).
} 
U.S. Department of Education Special Education Fund. The act authorized the Office of Special Education and Rehabilitation Services to allocate $\$ 12.2$ billion to states to assist local education agencies in providing free and appropriate public education (FAPE) to students with special needs. ${ }^{33}$

The lion's share of these grant monies came in the form of add-ons to the regular Individuals with Disabilities Education Act (IDEA) Part B funding. The Recovery Act funding formula follow the IDEA Part B formula. ${ }^{34}$ The national FFY2009 regular grant amount was $\$ 11.5$ billion. The first $\$ 3.1$ billion (both from regular funding and the Recovery Act add-on) was divided amongst states so that they were guaranteed to receive their FFY1999 awards. The remaining part of the national award was allocated among the states according to the following rule: " $85 \%$ are allocated to States on the basis of their relative populations of children aged 3 through 21 who are the same age as children with disabilities for whom the State ensures the availability of an FAPE) and 15\% on the relative populations of children of those ages who are living in poverty." 35 The Recovery Act add-on totaled $\$ 11.3$ billion. Since, at the margin, the FY1999 requirements had already been met by the regular awards, every Recovery Act dollar was in effect assigned according to the 85/15 percent rule.

Next and importantly, we address how funds were assigned from state education agencies to local education agencies (LEA). These initial allocations too were made at the federal level. Each LEA was first allocated a minimum of its FFY1999 award. ${ }^{36}$ Beyond these minimums, which were already met by the regular annual award amounts, a slightly different 85/15 rule was used. Within each state, $85 \%$ of dollars was allocated to according to the share of school age children in the LEA and $15 \%$ was allocated according the LEA's childhood poverty rate. After this, states were allowed to do reallocations as explained below. Before we explain how reallocations worked, we ask whether the observed spending data at the within state level is explained by the simple formulary rules.

Let $P_{j, s}$ and $\tilde{P}_{j, s}$ be the enrollment of students and students in poverty, respectively, in district $j$ and state $s$. Let $I D E A_{j, s}$ denote the total Recovery Act special needs funding in district $j$ in state $s$. Based on the above formula, the distribution of Recovery Act IDEA dollars would be

$$
I D E A_{j, s}=\left(0.85 \times \frac{P_{j, s}}{\sum_{i=1}^{N_{s}} P_{i, s}}+0.15 \times \frac{\tilde{P}_{j, s}}{\sum_{i=1}^{N_{s}} \tilde{P}_{i, s}}\right) I D E A_{s}
$$

Letting $P_{s}$ and $\tilde{P}_{s}$ denote the sum within state $s$ of the two district level enrollment variables, we

\footnotetext{
${ }^{33}$ Our discussion of the instrument here follows Dupor and Mehkari (2015), which uses the special education funding component of the act as an instrument to assess the effect on school districts' spending of the Recovery Act grants.

${ }^{34}$ See U.S. Dept. of Education (2009b) and New America Foundation (2014).

${ }^{35}$ Enclosure B of U.S. Dept. of Education (2009b) contains the precise description of how Recovery Act funds were allocated across states.

${ }^{36}$ Federal code also describes how minimum awards are determined for LEAs created after 1999.
} 
can rewrite thie above equation as:

$$
\frac{I D E A_{j, s}}{P_{j, s}}=\left[0.85 \times \frac{1}{P_{s}}+0.15 \times \frac{1}{\tilde{P}_{s}}\left(\frac{\tilde{P}_{j, s}}{P_{j, s}}\right)\right] I D E A_{s}
$$

Thus, within each state, the district level per pupil IDEA amount would be perfectly predicted by the ratio of the low-income enrollment to the overall enrollment in the district. By running state-level regressions (available on request) we show that this variable has very little predictive power for the IDEA per pupil amount. This tells us that other factors besides poverty rate in each district are influencing the allocation of IDEA funds.

This brings us to the rules for redistribution of dollars within state across LEAs, given by Code of Federal Regulation 300.707(c)(1). It states:

If an SEA determines that an LEA is adequately providing FAPE to all children with disabilities residing in the area served by that agency with State and local funds, the SEA may reallocate any portion of the funds under this part ... to other LEAs in the State that not adequately providing special education and related services to all children with disabilities residing in the area served by those LEAs.

We conclude that the primary reason that IDEA money was allocated differently from the formulary rule is that, within individual states, some localities were able to meet their funding requirements of special needs students without using any or all of the Recovery Act IDEA funds. Those funds were then reallocated to districts with additional funding for special needs students. Differences in funding requirements across districts were likely due to various factors, such as the number of special needs students, the types of disabilities and their associated costs and the districts' own funding contributions for providing the services to these special needs students. Our exogeneity assumption is that this set of factors driving redistributions of IDEA funds is orthogonal to the error term in second stage equation.

\section{A.3 Solution Method for Firm Problem}

We use function iteration on a grid to solve for the function $\mathscr{C}(e, G, \psi)$ given by equation (3.6). The grid has 501 points in the $e$ dimension and 101 points in the $\psi$ dimension. The points in the $G$ dimension depend on the value of $T$. For the baseline calibration $T=8$ and thus the function has 9 points in the $\mathrm{G}$ dimension; one each for the 9 different states of the economy in the $\mathrm{G}$ dimensions (i.e. one for $t \notin[1, T]$ and one each for $t \in[1, T]$ ). The expectations operator on the right hand side of (3.6) is solved by discretizing the uniform distribution over the 101 points in the $\psi$ dimensions.

Once we have $\mathscr{C}(e, G, \psi)$, we use it to construct a policy function $e_{t+1}\left(e_{t}, G_{t}, \psi_{t}\right)$. This policy function along with the exogenous processes for $G$ and $\psi$ fully describe the evolution of the state vector, $\left(e_{t}, G_{t}, \psi_{t}\right)$, for the firm. We can then use the state vectors along with equations (3.7) and 
(3.4) to determine the number of hours each employee works, $h_{t}$, the per employee wage, $w\left(h_{t}\right)$, and whether the firm adjusts the number of employees, for each period of our simulation

For the results in Table 10 and the impulse responses we simulate our model economy 30,000 times over different realizations of $\left\{\psi_{t}\right\}_{t=[0, \infty]}$. In this way our final results give us the expected response of the firm over the stochastic variable $\psi_{t}$. An alternative way to interpret our results is that they give the response of an average firm in an economy with 30,000 identical firms. 